IZA DP No. 6113

A New Approach to Testing Marginal Productivity Theory

Martin Biewen

Constantin Weiser

November 2011 


\title{
A New Approach to Testing Marginal Productivity Theory
}

\author{
Martin Biewen \\ University of Tübingen, \\ DIW Berlin and IZA
}

Constantin Weiser

University of Mainz

\section{Discussion Paper No. 6113 \\ November 2011}

\author{
IZA \\ P.O. Box 7240 \\ 53072 Bonn \\ Germany \\ Phone: +49-228-3894-0 \\ Fax: +49-228-3894-180 \\ E-mail: iza@iza.org
}

\begin{abstract}
Any opinions expressed here are those of the author(s) and not those of IZA. Research published in this series may include views on policy, but the institute itself takes no institutional policy positions.

The Institute for the Study of Labor (IZA) in Bonn is a local and virtual international research center and a place of communication between science, politics and business. IZA is an independent nonprofit organization supported by Deutsche Post Foundation. The center is associated with the University of Bonn and offers a stimulating research environment through its international network, workshops and conferences, data service, project support, research visits and doctoral program. IZA engages in (i) original and internationally competitive research in all fields of labor economics, (ii) development of policy concepts, and (iii) dissemination of research results and concepts to the interested public.
\end{abstract}

IZA Discussion Papers often represent preliminary work and are circulated to encourage discussion. Citation of such a paper should account for its provisional character. A revised version may be available directly from the author. 
IZA Discussion Paper No. 6113

November 2011

\begin{abstract}
A New Approach to Testing Marginal Productivity Theory*

We address the long standing question of whether production factors are paid their marginal products. We propose a new approach that circumvents the need to specify production functions and to compare marginal products to factor payments. Our approach is based on a simple equation that directly relates firms' profits to discrepancies between factor payments and marginal products. Our empirical application using data on manufacturing firms suggests that capital receives more than its marginal product, intermediate inputs receive less, and labor receives about its marginal product. Although there are differences with respect to firm size, deviations from marginal productivity theory generally seem limited. Our results have important implications for the distribution of income, the presence of optimizing behavior, and the existence of market power.
\end{abstract}

JEL Classification: D33, D22, D40

Keywords: marginal productivity theory, distribution of income, robust statistics

Corresponding author:

Martin Biewen

Department of Economics

University of Tübingen

Mohlstr. 36

72074 Tübingen

Germany

E-mail: martin.biewen@uni-tuebingen.de

\footnotetext{
*We thank Ben Jann for helpful discussions as well as Jaime Espina Ampuero (INE Chile), Luis Huergo, Markus Niedergesäss, and Nina Pavcnik for help with the data.
} 


\section{Introduction}

Derived from the assumption of individual maximization behavior and competitive markets, the hypothesis that production factors are paid their marginal products is one of the main ingredients of neo-classical economics. If one were to determine the share of contributions to theoretical or applied economics making these assumptions, one would come to the conclusion that there are few assumptions that are more widespread than the one that production factors are employed up to the point where their remuneration equals their marginal product. This is, of course, not to say that a large number of alternative theories about the determination of factor remunerations exist. Some of these theories will be discussed below. Given the great importance of marginal productivity theory however, it is puzzling that the task of testing this theory has received so little attention in the literature. The literature review presented below suggests that the number of studies explicitly testing marginal productivity theory is in stark contrast to the role this theory plays in economics.

In this paper, we take a fresh look at testing marginal productivity theory empirically. We propose a new approach that circumvents the need to specify a production function and compare the implied marginal products to factor payments. Our approach rests on the simple intuition that, if returns to scale are constant and production is homogenous, the fact that residual profits (or losses) exist is informative about whether each production factor was paid more or less than its marginal product. The fact that we do not need to explicitly specify a production function appears to be a major advantage over previous attempts to test marginal productivity theory as even small amounts of misspecification of the production technology may lead to the spurious finding that factor payments do or do not equal marginal products. Our setup is in this respect also much less restrictive than large parts of the economics literature which usually make the assumption that the production function is of the Cobb-Douglas form, the CES form, the Translog form, or similar parametric forms. We also do not make any behavioral assumptions such as profit maximization, or assumptions on price taking or price setting behavior. As a consequence, we will be able to carry out powerful tests of whether such assumptions are consistent with the data.

The validity or invalidity of marginal productivity theory has important implications for different areas. As indicated above, marginal productivity theory rests on the assumption that firms maximize profits (or minimize costs), and that markets are competitive. Any deviation from marginal productivity theory will therefore indicate a violation of either of these assumptions. 
Equality of factor payments and marginal products also plays an important role in considerations of allocative efficiency. For example, in the general setup of the first theorem of welfare economics, a necessary condition for allocative efficiency is that production factors are paid their marginal products. Another area which is directly connected to the remuneration of production factors is the distribution of income. Indeed, this was one of the earliest questions economists dealt with. Marginal productivity theory implies that each production factor receives the share it marginally contributes to the overall product. This has both positive and normative implications. ${ }^{2}$

The rest of this paper is structured as follows. In section 2, we give an overview over related literature we found. Section 3 presents the basic relationship between profits, factor payments and marginal products, which we use to test marginal productivity theory empirically. In section 4, we discuss our econometric methods. Section 5 presents our empirical results. In section 6 , we provide some interpretations of our findings, and section 7 concludes.

\section{Related Literature}

In this section, we review some related literature. One of the earliest attempts to test marginal productivity theory can be found in Bronfenbrenner/Douglas (1939) and Gunn/Douglas (1940, 1942). In these studies, the Cobb-Douglas production function is fitted to manufacturing data at the industry level, and implied marginal products are compared to industry wage averages. The authors conclude that deviations from marginal productivity theory are small. While the contribution of these papers to economics is undisputed (especially given the possibilities of data collection and analysis at the time), it is clear that the assumption of a Cobb-Douglas production function is very restrictive. Further limitations are the use of value-added output and data at the industry level which both imply difficult aggregation issues.

A slightly more sophisticated approach to testing marginal productivity theory is adopted by Stein (1958), who derives two implications from this theory and tests them using industry-level data on average wages. Stein's approach is also subject to the limitations described in the previous paragraph. Some of the problems that arise in studies that use Stein's methodology or the methodology of the very early contributions are discussed in a critique of Stein's article given in Archibald (1960).

\footnotetext{
${ }^{2}$ For a discussion, see e.g. Friedman (1976).
} 
Another attempt to test whether capital and labor are paid their marginal products is by Thurow (1968). Estimating different variants of aggregate Cobb-Douglas and CES production functions for the U.S. based on time series data on output, capital and labor for the years 1929 to 1965, the article contrasts the implied marginal productivities with observed aggregate returns to capital and labor over the same period. The author finds substantial discrepancies between implied marginal products and observed aggregate returns. He concludes that, as a consequence, the economy is in disequilibrium, and discusses possible reasons. Apart from the possible restrictiveness of the production function used, the approach used in Thurow's (1968) study clearly faces even more severe aggregation problems than the studies cited before. Thurow's result that capital receives more and labor receives less than its marginal product was also obtained earlier by Hildenbrand/Liu (1957) but based on industry data.

A general discussion of methodological problems involved in testing marginal productivity theory is provided by Gottschalk/Tinbergen (1982). They list a number of possible issues such as different forms of aggregation problems or the difficulty to find the correct specification for the production function. However, as we will show below, their claim that all tests of the marginal productivity theory need to first specify a production function and then compare implied marginal productivities to observed factor payments does not seem to be correct.

The first study that used a more disaggregated scheme of production factors in a test of the marginal productivity theory appears to be Gottschalk (1978). Using industry data, Gottschalk (1978) distinguishes between a number of different occupations in both production and administration. He also finds that capital receives more than it marginal product, while labor receives less. Moreover, his results suggest that there are a number of discrepancies between marginal productivity and wages paid across occupations. Apart from the use of industry level data, Gottschalk's results are also subject to the criticism that a very specific production function is assumed, and that value-added data is used. In addition to theoretical problems that may arise when working with value-added data, ${ }^{3}$ the implied omission of intermediate inputs as production factors does not allow one to address whether these factors receive more or less than their marginal products, and it may bias the results on the validity of the marginal productivity theory for the input factors explicitly included.

\footnotetext{
${ }^{3} \mathrm{~A}$ general critique of using value added data in studies involving production functions is given in Basu/Fernald (1995).
} 
One of the first studies that uses micro-economic data in a test of the marginal productivity hypothesis is Frank (1984). Recognizing the fact that it is hard to estimate marginal productivity in production processes that involve more than one factor, he focuses on a number of occupations in which marginal productivity is relatively easily observed. The special focus of the paper is on wage and productivity differences within a given institution rather than on deviations from marginal productivity theory in general. Using data on automobile and real estate sales persons as well as on university professors, and making a number of assumptions on the production technology and firm behavior, the study finds that wages are more compressed within institutions than productivities. This is an interesting result, although it is unclear to what extent it can be generalized to occupations or sectors other than the ones considered.

Using a highly informative employer-employee data set, Hellerstein et al. (1999) also examine whether wage differences between different types of workers are consistent with differences in estimated marginal productivities. Hellerstein et al. (1999) use micro-data, they distinguish between different types of labor, and they include materials as a production factor in their estimated production function. In our view, their study is one of the very few genuine empirical studies of the marginal productivity hypothesis. A limitation of their contribution is that they make explicit functional form assumptions when specifying the production function. Moreover, as some of the other studies cited above, Hellerstein et al. (1999) only examine deviations from the marginal productivity theory for the factor labor, but not for capital or intermediate inputs. Their results suggest that relative wages indeed reflect relative marginal productivities, except for the case of gender wage differentials. Using a very similar approach, Hellerstein/Neumark (1999) investigate gender wage and productivity differentials in firm data from Israel. The conclusion of this study is that relative wage differences with respect to gender are consistent with relative marginal productivities. ${ }^{4}$

A very exciting recent study that addresses many of the issues we consider below is Dobbelaere/Mairesse (2011). Using panel data on French firms, Dobbelaere/Mairesse (2011) develop a comprehensive approach to the joint estimation of production functions and imperfections in product and labor markets. They theoretically distinguish between six different regimes characterized by the perfectness or imperfectness of the product market and different bargaining regimes for the labor market. They then show how to nest these six regimes in a regression analysis

\footnotetext{
${ }^{4}$ Hellerstein et al. (1999) and Hellerstein/Neumark (1999) only make statements about relative deviations from marginal productivity. This is something we will also relax below.
} 
that identifies the different parameters of market imperfections and bargaining regimes. Their empirical results suggest that the predominant regime is one of imperfect competition in the product market and efficient bargaining in the labor market (which implies that labor receives more than its marginal product). We believe that with their results, Dobbelaere/Mairesse (2011) make a substantial contribution to the literature. When we compare what assumptions they make which we do no have to make, we find that their specification of the production function as Cobb-Douglas is probably restrictive, and that they do not allow for the possibility of imperfect input markets (which is something we allow for). On the other hand, they are in the position to consider in great detail heterogeneity across firms and industries, which is something we will not be able to address. ${ }^{5}$

\section{Profits and Marginal Productivity}

In this section, we derive a simple equation that relates firms' profits to discrepancies between factor payments and marginal products. To arrive at this equation, we only make the assumption that the firms' production function is homogenous, and that production at the firm level exhibits constant returns to scale. We acknowledge that both assumptions may not be uncontroversial. However, both of them are commonly made in both theory and empirical applications, suggesting that our approach is not more restrictive than other approaches in the literature. Moreover, we make no further assumptions on the parametric form of the production function, which makes our approach less restrictive than much of the literature. As to the assumption of constant returns to scale, there appears to be a consensus based on a large number of studies using a variety of methodologies and data sets for different countries, suggesting that returns to scale are constant at the firm level. Examples include Griliches/Ringstad (1971), Nguyen/Reznek (1991), Baily et al. (1992), Westbrook/Tybout (1993), Bregman et al. (1995), Levinsohn/Petrin (2003), Abraham/White (2006), and Basu et al. (2009). Evidence based on industry level data is more mixed, but findings presented, for example, in Basu/Fernald (1995, 1997), Burnside et al. (1995), Oulton (1996), and Inklaar (2007) also suggest that there is little evidence against the hypothesis that returns to scale are constant. We will also show that, if the assumption of constant returns to scale is not met, our results can be interpreted as upper or lower bounds to the amount of

\footnotetext{
${ }^{5}$ We have to deal with sample size restrictions and the fat-tailedness of our data (see below). We will consider firm size heterogeneity, however.
} 
over-/underpayment of production factors compared to their marginal products.

We start with the accounting identity stating that revenues are equal to the sum of costs for the different production factors, profits, and taxes

$$
\begin{aligned}
P Y & =\text { capital costs }+ \text { labor costs }+ \text { intermediate inputs }+ \text { profits }+ \text { taxes } \\
& =r K+w L+q I+\text { profits }+ \text { taxes }
\end{aligned}
$$

where $P$ denotes product price, $Y$ real output, $K, L, I$ the input quantities of capital, labor, and intermediate inputs and $r, w, q$ their per-unit prices. Capital costs are meant to include all explicit payments to capital holders, i.e. interest payments to creditors as well as dividends and other withdrawals of equity by equity holders. Note that residual profits (or losses) retained in the firm automatically accrue to the firm's owners and will therefore have to be taken into account when assessing whether or not capital is over-/underpaid with respect to its marginal productivity (see below).

Assuming homogeneity and constant returns to scale, real output $Y$ can be written as

$$
Y=f_{K} K+f_{L} L+f_{I} I
$$

where $f_{K}, f_{L}, f_{I}$ denote the marginal products of capital, labor and intermediate inputs.

Combining (1) and (2) yields the basic equation

$$
\pi=\left(\frac{\text { profit }+ \text { taxes }}{P}\right)=\left(f_{K}-\frac{r}{P}\right) K+\left(f_{L}-\frac{w}{P}\right) L+\left(f_{I}-\frac{q}{P}\right) I
$$

i.e. real profits before taxes are the sum of deviations between factor payments and marginal products, weighted by input quantities. Equation (3) will be our basic vehicle for testing whether factor payments equal marginal products.

In the following, we will use the notation

$$
\pi=\beta_{K} K+\beta_{L} L+\beta_{I} I
$$

with $\beta_{K}=\left(f_{K}-\frac{r}{P}\right), \beta_{L}=\left(f_{L}-\frac{w}{P}\right)$ and $\beta_{I}=\left(f_{I}-\frac{q}{P}\right)$. The case in which a particular production factor, e.g. labor, can be subdivided into different categories $L_{1}, L_{2}, \ldots, L_{k}$ yields the analogous equation

$$
\pi=\beta_{K} K+\beta_{L_{1}} L_{1}+\beta_{L_{2}} L_{2}+\cdots+\beta_{L_{k}} L_{k}+\beta_{I} I .
$$


The amount of over-/underpayment of production factor $K, L_{1}, L_{2}, \ldots, L_{k}, I$ can directly be read off equation (5). Coefficients $\beta$ that are greater than zero indicate underpayment, coefficients that are less than zero indicate overpayment of a factor when compared to its marginal product. The magnitude of $\beta$ directly represents the amount of over-/underpayment per unit of the production factor in question, measured in real money units.

\section{Data}

In order to implement our approach we need sufficiently informative data. For our empirical application use a rich panel data set on Chilean manufacturing plants earlier versions of which have been used in a number of well-known studies. ${ }^{6}$ The data set is called ENIA ('Encuesta Nacional de la Industria Manufactuerera') and was generously provided to us by the Instituto Nacional de Estadisticas de Chile (INE). Our unbalanced panel covers 6,634 manufacturing plants (most of which are single-plant firms) over the years 2001 to $2006 .{ }^{7}$ A particular advantage of our data set is that it includes - besides general information on revenues, costs, intermediate inputs and capital - detailed information on different types of labor inputs. In particular, we will be able to study whether, and to what extent, different types of labor such as low/high-skilled labor, managerial labor etc. receive more or less than their marginal product.

In the following, we give a description of the main variables used in our analysis. Our main dependent variable is real profit before taxes (see eq. (3)), which was constructed as revenues minus all costs (excluding taxes). As indicated above, we include in the capital costs all explicit payments to either creditors or equity holders, i.e. we also include dividend payments and reported withdrawals of equity in the case of non-incorporated firms. We deflate profits with a series of low-level deflators (base year $=2003$ ) at the four-digit industry level ('Clasification Industrial Internacional Uniforme de todas las actividades economicas', CIIU Rev.3) which is available from the INE. Firms' capital is measured in book values and was deflated by a deflator for capital goods also provided by the INE. Intermediate inputs comprise all non-labor and non-capital inputs used by the plant to produce output. We deflated intermediate inputs using a series of low-level

\footnotetext{
${ }^{6}$ See, for example, Lui (1993), Westbrook/Tybout (1993), Pavcnik (2002), Levinson/Petrin (2003, 2008).

${ }^{7}$ We do not use earlier years because i) the questionnaires were changed in 2001 rendering many variables incomparable over time, ii) time-consistent, low-level price deflators for inputs and output are only available for the period 2001 - 2006, and ii) the period 2001 - 2006 was one of stable business cycle conditions, see below.
} 
deflators for different types of intermediate inputs at the four-digit industry level. Labor input is measured in hours per year for different labor categories. We can distinguish between labor input by owners, managers, high-skilled workers that carry out tasks directly related to production, low-skilled workers that carry out tasks directly related to production, low-skilled workers that carry out tasks indirectly related to production, administrative personnel (accounting, electronic data processing, excluding secretarial staff), other services (secretarial staff, catering, drivers, security, cleaning personnel), and sales personnel.

Our data set is large enough to allow us to split our sample into several subsamples according to plant size. This ensures that the plants under consideration are sufficiently homogenous, and it allows us to consider heterogeneity between plants of different size. We define three groups i) plants with 10 to 25 workers, ii) plants with 26 to 100 workers, and iii) plants with 101 to 1000 workers. We also analyze the total sample comprising plants with 10 to 1000 workers. ${ }^{8}$ Summary statistics for our main variables in all subsamples and in the total sample are given in tables 14 to 17 in the appendix.

Figures 1 to 3 present some additional information for the total sample along with information on the macro-economic environment during the period under consideration. The figures show that the period 2001 to 2006 was one of stable growth both for the manufacturing sector and the rest of the economy with almost constant and moderate inflation rates. Figure 2 shows in addition that low-skilled production workers provided by far the highest share of labor input, followed by high-skilled production workers. Labor input by other types of labor was less substantial.

- Figures 1 to 3 about here -

\section{Econometric Implementation}

Our goal is to estimate variants of eq. (3) on our data. However, our initial attempts using OLSmethods yielded very unrobust and implausible results. The reason is that most of our variables, in particular our dependent variable (profit before taxes), turn out to be highly leptokurtic, i.e. they are characterized by a large share of extreme observations (see tables 14 to 17 ). A common way

\footnotetext{
${ }^{8}$ The subsamples were defined so that each subsample comprised sufficiently many observations. We excluded the small fraction of even larger plants as this would have added an extremely heterogenous group of plants and would have exacerbated problems with outlying observations, see the discussion below.
} 
to deal with non-normal, highly leptokurtic variables in regression analysis is to trim the sample, e.g. to discard the top and the bottom $1 \%$ of the data. Figure 4 compares the distribution of our dependent variable and that of important covariates with the distribution after trimming for the subsample of firms with 10 to 25 workers. It is clear that discarding the top and the bottom $1 \%$ of observations reduces the problem but still results in an extremely leptokurtic distribution. This is all the more remarkable as, by construction, the subsample of firms with 10 to 25 workers should be expected to exhibit a relatively high degree of homogeneity. We gradually extended the share of discarded observations but this only led to a sequence of varying and unrobust estimation results which were also erratic across alternative specifications. ${ }^{9}$ Even if one accepts the method of gradually excluding extreme observations, one faces the problem that there is no natural way to decide how large the share of excluded observations should be. This unsatisfactory situation clearly calls for a more systematic approach.

- Figure 4 about here -

Robust methods for data characterized by a potentially large share of 'outlying' observations have a long tradition in statistics, but have received relatively little attention in econometrics. A good reference for robust statistical methods is Maronna et al. (2006). Up-to-date robust regression routines have recently been made available for Stata by Verardi/Croux (2009) and Jann (2010). ${ }^{10}$ The goal of robust methods is to provide estimation procedures that are robust in the sense that estimation results are not overly influenced by the presence of extreme observations, while retaining efficiency properties in the case when the data is not excessively characterized by outlying observations (e.g. in the case of a Gaussian error distribution). The overall robustness of an estimator can be characterized by the so-called breakdown point which is defined as the share of extreme observations up to which the influence of such observations on the estimates remains bounded.

In the following, we use the so-called MM-estimator developed by Yohai (1987) which combines a high breakdown point and a high Gaussian efficiency. ${ }^{11}$ For the regression

$$
y_{i}=\theta_{0}+\theta_{1} x_{1 i}+\cdots+\theta_{p} x_{p i}+\varepsilon_{i}=\theta x_{i}+\varepsilon_{i}
$$

\footnotetext{
${ }^{9}$ Similar experiences when using similar firm data are reported in Verardi/Wagner (2010).

${ }^{10}$ We use these routines for our estimations.

${ }^{11} \mathrm{~A}$ good description of this estimator is given in Verardi/Croux (2009).
} 
the MM estimator is defined as

$$
\hat{\theta}_{M M}=\arg \min _{\theta} \sum_{i=1}^{n} \rho\left(\frac{r_{i}(\theta)}{\hat{\sigma}^{S}}\right)
$$

where $r_{i}(\theta)=y_{i}-\theta_{0}+\theta_{1} x_{1 i}+\cdots+\theta_{p} x_{p i}$ and $\hat{\sigma}^{S}$ is a robust estimator of scale which is determined in a previous step, see below. The function $\rho(\cdot)$ is usually chosen as the Tukey Biweight function

$$
\rho(u)= \begin{cases}1-\left[1-\left(\frac{u}{k}\right)^{2}\right]^{3} & \text { if }|u| \leq k \\ 1 & \text { if }|u|>k\end{cases}
$$

The intuition behind the estimator defined in (7) and (8) is clear: instead of considering squared residuals when minimizing the sum of deviations from the regression plane, each residual undergoes a transformation $\rho(\cdot)$ such that the influence of large residuals is dampened (depending on the constant $k$ ).

For the MM estimator, the normalizing scale $\hat{\sigma}^{S}$ is robustly determined in a first step in

$$
\frac{1}{n} \sum_{i=1}^{n} \rho\left(\frac{r_{i}\left(\hat{\theta}_{S}\right)}{\hat{\sigma}^{S}}\right)=E(\rho(Z)) \quad \text { with } Z \sim N(0,1)
$$

where

$$
\hat{\theta}_{S}=\arg \min _{\theta} \hat{\sigma}^{S}\left(r_{1}(\theta), r_{2}(\theta), \ldots, r_{n}(\theta)\right)
$$

The estimator $\hat{\theta}_{S}$ is called an S-estimator and also has got robustness properties. Yohai (1987) has shown that combining the first step S-estimator in order to estimate the scale parameter $\hat{\sigma}^{S}$ with the second step estimator defined in (7) leads to an estimator $\hat{\theta}_{M M}$ with a high breakdown point and a high efficiency in the Gaussian case. Following Maronna et al. (2006), we chose a breakdown point of $50 \%$ and an efficiency relative to the Gaussian case of $85 \%$, which requires setting $k=1.55$ for the first step S-estimator and $k=3.44$ for the second step estimator. ${ }^{12}$

\footnotetext{
${ }^{12} \mathrm{~A}$ higher Gaussian efficiency leads to a higher bias caused by outlying observations. We also experimented with lower breakpoints and higher/lower efficiencies. This did not change our results in any important way.
} 


\section{Empirical Results}

Before we can present our empirical results, we have to return to the point that residual profits (or losses) will eventually be owned by capital holders and are therefore a part of the payments to the input factor capital. Profits (after taxes) have therefore also to be subtracted when calculating the amount of over-/underpayment for the factor capital when compared to its marginal product.

The total amount of over-/underpayment per unit of capital is therefore given by

$$
\left(f_{K}-\frac{r}{P}\right)-\frac{\frac{\text { profit }}{P}}{K}=\beta_{K}-\frac{\frac{p \text { rof } i t}{P}}{K}=\tilde{\beta}_{K}
$$

We therefore also report in our results the mean of $\tilde{\beta}_{K}$ over all firms in the sample.

In our initial estimations we noticed that for a number of firms, the ratio of profits/losses to capital appearing in (11) was implausibly high or implausibly negative. In order to avoid that the estimates of the average of $\tilde{\beta}_{K}$ across firms were overly influenced by such extreme values, we dropped firms in the bottom $1 \%$ and those in top $1 \%$ of the distribution of the profit to capital ratio. Similarly, we detected a number of implausibly low or implausibly high values of the hourly wage paid in a firm (which was computed as the firm's cost of labor divided by the number of hours employed by the firm). In some cases, this led to an implausible ranking of hourly wages across qualifications which was corrected when we dropped very extreme observations (which may always be a result of measurement/coding errors). We therefore also dropped the bottom $1 \%$ and the top $1 \%$ of hourly wage observations. Apart from these two adjustments, we did not alter our data in any way. We emphasize that omitting the bottom and top $1 \%$ of profit to capital ratio and hourly wage observations did not change our robust regression results of our central equation (3) in any important way. The adjustments described were solely made in order to avoid implausible summary statistics for hourly wages and the quantity in (11).

\subsection{Pooled Robust Regression}

Our results from applying the robust MM-estimator to the four samples (firms with 10 to 25 workers, firms with 26 to 100 workers, firms with 101 to 1000 workers, and firms with 10 to 1000) are shown in tables $1,3,5$, and 7 . For our estimations, we pooled in each subsample firm 
observations over the years in order to increase the number of observations used in estimation. ${ }^{13}$

Table 1 shows the results for the group of firms with 10 to 25 workers. The first entry in column 1 suggests that capital's direct remuneration falls short of its marginal product by $6.15 \% .{ }^{14}$. If profits and losses are included, capital is even more underpaid when compared to its marginal product, namely by almost $13 \%$ on average. It seems surprising that including profits decreases capital's remuneration but this is easily explained by the fact that over $50 \%$ of the firms with 10 to 25 workers actually operate with losses (see the second row of table 14). The cost of intermediate inputs also falls short of their marginal contribution to output. More precisely, the underpayment of intermediate inputs amounts to $4.2 \%$ pesos per peso spent on intermediate inputs. By contrast, the factor labor seems to be slightly overpaid when compared to its marginal product. The overpayment amounts to .1259 thousand pesos per hour. In order to assess whether this is a large or a small amount, one can compare this figure to the average hourly wage in firms with 10 to 25 workers, which is 2.034 thousand pesos (see first row of table 2). Taken together, this suggests that labor (including the labor input by owners) is overpaid by an amount of some $5 \%$ on average.

- Tables 1 and 2 about here -

The other columns of table 1 show some alternative specifications at different aggregation levels of the factor labor. The second but last column reveals that the observed direct remuneration of owners' labor substantially exceeded the corresponding marginal product. According to the estimates, owners' labor was overpaid by 1.0501 thousand pesos per hour worked, which amounts to an overpayment of some $22 \%$ (the average hourly wage for labor supplied by owners was 4.655 thousand pesos, see table 14). This finding helps to resolve the puzzle that firms in this size category systematically seem to make losses. It appears that owners extract part of the remuneration that should actually be attributed to their capital through the remuneration of their labor which exceeds its marginal product. This is plausible given the small size and the probably

\footnotetext{
${ }^{13}$ We also carried out regressions by year. They conveyed a similar picture, but in many cases coefficients were just statistically insignificant.

${ }^{14}$ According to equation (4) capital is underpaid by an amount of .0615 times 1000 Chilean pesos per 1000 Chilean pesos capital invested (all variables except labor are expressed in thousands of Chilean pesos), or equivalently, by .0615 pesos per peso invested. The over-/underpayment of intermediate inputs has a similar interpretation. It is the peso amount of over-/underpayment per peso spent on intermediate inputs. The interpretation of the labor coefficient is the over-/underpayment in thousands of pesos per unit of labor (i.e. per hour).
} 
mostly unincorporated nature of these firms. The point that owners' income from capital and the remuneration of their labor are likely to mix up in practice is also considered in detail in Gollin (2002). The second but last column of table 1 suggests that managers in firms with 10 to 25 workers were also slightly overpaid (by some $7 \%$ ), similarly low skilled production workers (by $10 \%$ ) and sales personnel (by 6\%), although many of these effects are only marginally significant. The intermediate results in column table 1 demonstrate that the estimates are consistent across different levels of aggregation of the factor labor.

Turning to the results for firms with 26 to 100 workers, the first entry in table 3 suggests that, not taking account of profits, capital is underpaid by some $6.55 \%$. If profits are taken into account, capital is actually overpaid by about by $13.65 \%$ when compared to its marginal product. Labor as a whole is also slightly overpaid when compared to its marginal product. The overpayment amounts to 198.5 pesos per hour, which is about $7.8 \%$ above the marginal product of an additional hour of labor (the hourly wage of labor employed in firms with 26 to 100 workers is 2.530 thousand pesos, see table 4). Again, the amount paid by the firms for intermediate inputs falls short of their marginal contribution to production of output. The underpayment of intermediate inputs amounts to some 5\%. Overall, it seems that firms with 26 to 100 workers generate rents from underpaying intermediate products which are distributed to labor and capital. Again, the second but last column gives more detailed results as to which types of labor are overpaid. It seems that in particular, high-skilled production workers are slightly overpaid (by some 4\%), similarly lowskilled production workers (by some 9\%), and, in particular, low-skilled workers whose work is only indirectly related to production (by some 18\%). Note however, that in most cases these effects are only marginally significant. For all other labor categories, one cannot reject the hypothesis that their remuneration equals their marginal contribution to producing output at any conventional significance level.

\section{- Tables 3 and 4 about here -}

The results for firms with 101 to 1000 workers are given in table 5. Again, capital is underpaid compared to its marginal product when profits are not taken into account. However, if profits are included, the remuneration of capital exceeds its marginal product by 358.4 pesos per 1000 pesos invested. Again, intermediate inputs are underpaid compared to their marginal contribution. The amount of underpayment is higher for these larger firms than for the smaller firms discussed above (some $9 \%$ compared to 4 or $5 \%$ ), which is plausible as larger firms probably have more market 
power on input markets (see the additional discussion below). The factor labor receives about its marginal product in firms with 101 to 1000 workers (see fifth row of table 5). In these firms, workers seem to have less bargaining power compared to smaller firms in which the factor labor appeared to engage in rent sharing with the factor capital. A closer look at different types of labor (see second but last column of table 5) reveals that none of the different labor groups manages to earn more than their marginal products (except maybe owners which however represent only a tiny fraction of workers in the given size class of firms).

- Tables 5 and 6 about here -

Finally, table 7 displays the results for the whole sample, i.e. for firms with 10 to 1000 workers. The results nicely reflect the average findings over the three size categories considered earlier. Capital is underpaid by some $8 \%$ if profits are not taken into account, and overpaid by some $9 \%$ if profits are taken into account. Intermediate inputs are slightly underpaid (by $3 \%$ ), while labor receives about its marginal product. The fact that the remuneration of labor supplied by owners exceeds their marginal product in small firms is still visible in the aggregate results for the whole manufacturing sector. Taken together, while there are some differences with respect to firm size, the results for the whole manufacturing sector suggest that there are some deviations from marginal productivity theory on average (capital receives more, intermediate inputs less than their marginal products), but the overall picture fits surprisingly well with the hypothesis that the remuneration of production factors follows their marginal productivity.

- Tables 7 and 8 about here -

\subsection{OLS on Robust Subsample}

As a robustness check and in order to prepare the fixed-effects estimations presented below, we also carried out OLS estimations on a subsample which was 'cleaned' of outliers. A major virtue of robust statistical methods is that they are not only robust to (potentially substantial amounts of) outlying observations but that they also provide ways to identify outlying observations. In the following, we exclude (in each subsample) observations that are outliers in the sense that they are too far from the (robustly estimated) regression hyperplane. Our precise definition of an outlier is an observation for which $\left|r_{i}\left(\hat{\theta}_{M M}\right) / \hat{\sigma}^{S}\right|>c_{0.99}$, where $c_{0.99}$ is the 99th percentile of the 
standard normal distribution (this is motivated by the fact that the standardized MM-residuals asymptotically follow a standard normal distribution). ${ }^{15}$ Tables 18 to 21 in the appendix show the results for OLS on the robust subsamples. The estimates are almost identical to those of the MM-regressions but standard errors are in many cases much lower (which is to be expected given that the elimination of outliers also reduces sample variability).

\subsection{Fixed-Effects Estimation on Robust Subsample}

In order to rule out that our estimates are biased by endogeneity problems due to omitted unobserved productivity determinants, we also conducted fixed-effects within-estimations on the subsamples cleaned of outliers. These results are reported in tables 9 to 12 . In principle, the estimates are similar to OLS on the robust subsample or MM-estimation on the full sample, but the coefficients generally appear to be attenuated towards zero. For example, in firms with 10 to 25 workers, the underpayment of capital (in the case where profits are ignored) is about $3 \%$ compared to $6 \%$ in the robust regression case (see table 1 ). Also, the underpayment of intermediate inputs and the overpayment of labor vanishes, if the fixed-effects estimator is applied to the robust subsample of firms with 10 to 25 workers. Similarly, in the case of firms with 26 to 100 workers, the underpayment of intermediate inputs and the overpayment of labor is also reduced towards zero (table 10). In the case of firms with 101 to 1000 workers, fixed-effects estimation on the robust subsample suggests that real intermediate inputs and labor receive about their marginal product, whereas capital is overpaid (if profits are taken into account, see table 11). This result is economically inconsistent as under the assumption of constant returns to scale, one production factor can only be overpaid if another one is underpaid. Finally, the fixed-effects results for the whole sample shown in table 12 are again very close to the corresponding robust regression results in table 7 , except that the coefficients seem slightly attenuated towards zero.

It is well known that the within-estimator is much more susceptible to measurement error than OLS methods as the signal to noise ratio may be drastically reduced by applying the within-

\footnotetext{
${ }^{15}$ In this way, we exclude so-called 'vertical outliers' as well as 'bad leverage points', see e.g. Verardi/Croux (2009) or Dehon et al. (2009). We do not exclude so-called 'good leverage points' which lie near the regression hyperplane but are characterized by extreme values of the covariates. Dehon et al. (2009) argue that not excluding good leverage points may in some cases lead to an overestimation of statistical significance. As we are interested in detecting (possibly small) deviations from marginal productivity theory, it seems more appropriate not to exclude good leverage points as they are likely to add statistical power.
} 
transformation. In this case, the within-estimator may even be more biased than the OLS estimator (Griliches/Hausman (1986)). Our evidence points in this direction as the within-estimates are uniformly attenuated towards zero when compared to the OLS and MM regression results. In any case, given that OLS and within-estimates are generally quite close, we conclude that our previous estimates are not systematically biased due to the omission of unobserved productivity differences. If anything, the fixed-effects results move our evidence further in the direction of the full validity of the marginal productivity theory.

\subsection{Other Estimators}

We have also experimented ${ }^{16}$ with the robust fixed effects estimators described in Bramati/Croux (2007), which are based on carrying out a 'robust' within-transformation (using the median instead of the mean over time) and then applying robust estimators to the transformed data. This basically led the situation that all regression coefficients were equal to zero, both in economic and statistical terms. As indicated above, such a result is economically inconsistent under the assumptions made if non-zero profits are present, as it would imply that capital is overpaid, but no other factor is underpaid. If anything, this would only be consistent under decreasing returns to scale as, in this case, marginal productivity remunerations do not exhaust the overall product so that one factor necessarily receives more than its marginal product. ${ }^{17}$ However, there is no empirical evidence for decreasing returns at the firm level (see section 3), and decreasing returns at the firm level are implausible from a theoretical point of view if profits are present (see Basu/Fernald (1995), p. 182, and below). We find it more likely that the result that all regression coefficients are equal to zero is due to the fact that the fat-tailedness of our data reduces the signal to noise ratio of our variables after the within-transformation so much that no significant relationships can be identified.

Finally, we have also tried out the methods introduced by Arellano/Bover (1995) and Blundell/Bond (2000), which are based on first-differencing and using lagged variables as instruments. Apart from the fact that in many cases overidentification tests failed, these methods also led to results that were economically implausible (or even nonsensical), or inconsistent over specifications (for example results contradicted each other when different aggregation levels of the factor

\footnotetext{
${ }^{16}$ Results are available on request.

${ }^{17}$ In the case of increasing returns to scale, marginal productivity remunerations add up to more than the overall product, see below.
} 
labor were used). We therefore conclude that these methods are ill-suited for our kind of fat-tailed data (similar experiences are reported in Levinsohn/Petrin (2003), p. 336). The same is true for methods using the Swamy methodology such as the ones applied in Dobbelaere/Mairesse (2011). Apart from the fact that our sample sizes seem too small to estimate heterogeneity distributions, these methods are also based on least squares and therefore seem ill-suited for our data.

\section{Interpretation of Results}

\subsection{Explanations for Deviations from Marginal Productivity Theory}

Our results suggest moderate deviations from marginal productivity theory in some cases. How can such deviations be explained? We start with a basic model of profit maximization in possibly imperfect input and output markets. The firm maximizes profit

$$
\pi=P(Y) Y-r(K) K-w(L) L-q(I) I \quad \text { with } Y=f(K, L, I)
$$

where $P(Y)$ denotes the inverse demand function for output, and $r(K), w(L), q(I)$ the inverse supply functions for inputs (with $P^{\prime}(Y) \leq 0, r^{\prime}(K) \geq 0, w^{\prime}(L) \geq 0$ and $q^{\prime}(I) \geq 0$ ). Profit maximization then implies

$$
f_{K}=\frac{r}{P} \cdot \frac{\left(1+\varepsilon_{r, K}\right)}{\left(1+\frac{1}{\varepsilon_{Y, P}}\right)}, \quad f_{L}=\frac{w}{P} \cdot \frac{\left(1+\varepsilon_{w, L}\right)}{\left(1+\frac{1}{\varepsilon_{Y, P}}\right)}, \quad f_{I}=\frac{q}{P} \cdot \frac{\left(1+\varepsilon_{q, I}\right)}{\left(1+\frac{1}{\varepsilon_{Y, P}}\right)}
$$

where $\varepsilon_{Y, P}, \varepsilon_{r, K}, \varepsilon_{w, L}, \varepsilon_{q, I}$ are the elasticities of the inverse demand and the inverse supply functions, respectively. The first order conditions show that profit maximization requires that production factors are always paid their marginal product or less, equality holding in the case of perfect competition in the output market $\left(\varepsilon_{Y, P}=-\infty\right)$ and in the input markets $\left(\varepsilon_{r, K}=\varepsilon_{w, L}=\varepsilon_{q, I}=0\right)$. This means that under profit maximization a production factor will never receive more than its marginal product, and underpayment of a factor is consistent with either monopolistic power in the output market $\left(\varepsilon_{Y, P}=-c<0\right)$, or market power in the input markets (for example, $\varepsilon_{w, L}>0$ or $\varepsilon_{q, I}>0$ ).

We found moderate but significant overpayment of capital, and, in some cases, of labor. While overpayment of capital can be explained by the fact that residual profits automatically accrue to 
capital owners (see below), a direct implication of an overpayment of (non-owners') labor would be that firms' behavior is not entirely consistent with pure profit maximization. Moreover, the fact that labor is over- rather than underpaid in some cases implies that our data provides little evidence for theories of monopsonistic labor demand stating that employers exploit immobility, search frictions or preference heterogeneity on the side of the employees in order to capture part of their marginal product (Bhaskar et al. (2002), Manning (2003), Cahuc/Zylberberg (2004)). On the other hand, our result that intermediate inputs are to a certain extent underpaid is consistent with the hypothesis that firms exert some market power in markets for intermediate inputs. This is plausible given that long-term relationships between firms and their suppliers may enable the firms to enforce lower prices. A plausible prediction arising from the hypothesis that firms exert market power in intermediate input markets is that their monopsonistic power is the greater, the larger the firm is. This prediction is supported by our results, i.e. the amount of underpayment increases with firm size (see third row of tables 1, 3 and 5).

Another general explanation for factor payments below marginal products is uncertainty (output price uncertainty and demand uncertainty). In the case of uncertainty, risk-averse firms will underpay (and underuse) inputs (Leland (1972) and Batra/Ullah (1974)). However, as we do not observe underpayment of all production factors (we only observe underpayment of intermediate inputs), we conclude that uncertainty plays no leading role in explaining differences between factor payments and marginal products, or at least, it is dominated by other factors. Similarly, even without monopsonistic power in input markets $\left(\varepsilon_{r, K}=\varepsilon_{w, L}=\varepsilon_{q, I}=0\right)$, factor remunerations may fall short of marginal products if the firm has monopolistic power in the output market $\left(\varepsilon_{Y, P}=-c<0\right)$. Again, as we do not observe uniform underpayment of all production factors (we only observe underpayment of intermediate inputs), we conclude that monopolistic power in the output market is unlikely to be the only explanation for differences between factor remunerations and marginal products, At least in the case of capital and labor, there must be other aspects that dominate a possibly depressing effect of monopolistic power in output markets on factor remunerations.

What are other aspects that possibly explain the (in some cases) existing overpayment of capital and labor over their marginal product? In the case of capital, an explanation is easy as the firms' owners may capture any residual income resulting after all other production factors have been remunerated. They may even extract parts of the firm's equity as a payment, although this would run down the firm's capital stock and therefore the firm owners' assets. However, it is interesting that in our data capital is only overpaid (compared to its marginal product) if residual profits are 
taken into account. Our results suggest that even if all explicitly reported payments to capital holders are counted (interest payments, dividends and other payments to equity holders), the payments to capital holders fall short of their marginal contribution to output (see first row of the tables showing the regression results). It is only after the residual income retained in the firms (this is our variable profit) are attributed to capital holders that capital's remuneration on average exceeds its marginal contribution to output. ${ }^{18}$

What are possible explanations for an overpayment of the factor labor? A leading model that potentially explains how wages can exceed marginal products is McDonald/Solow (1981). In this model, employees have bargaining power allowing them to bargain with employers at the firm level over both wages and employment. The intuition of the model lies in the insight that the same level of profits may be reached with a higher employment than the firm would choose if bargaining was only over wages, or if firms were price-takers with respect to wages. As employees prefer more employment to less employment, efficient bargaining then implies that employment is extended to a point where the marginal product of labor is already below the paid wage. The model requires that employees have bargaining power. Possible sources of bargaining power are worker unionization on the one hand, and the costs of firing, hiring and training workers on the other. Unionization in Chile is relatively low (see Lawrence/Ishikawa (2005)) but employees may be in the position to exploit the fact that it is costly to replace them.

A similar argument is used in insider-outsider models, where wages may rise up to the point where they equal marginal products plus turnover costs (Lindbeck/Snower $(1987,1988)$, Solow (1985)). Turnover costs consist of the direct costs of hiring and firing but may also include the potential loss of specific human capital caused by the exit of workers who previously received training in the firm. Cahuc/Zylberberg (2004, p. 264) describe the hold-up problem that arises when firms have the opportunity to invest in workers' specific human capital, leading to the situation that they have to share the returns to this investment (and associated investments in production technologies) with the workers. Note that in our data, we observe some (not very substantial) overpayment of the factor labor only in small and medium-sized firms. This may indicate that, in the absence of wide-spread official collective bargaining by trade unions, there may be implicit bargaining between employers and workers at the firm level, which is easier in small and medium-sized firms where the work force is smaller. Also, the personal relationship

\footnotetext{
${ }^{18} \mathrm{An}$ exception are small firms where we suspect that remunerations of owners' capital mix up with remunerations of their labor inputs, see above.
} 
between employees and firm owners tends to be much closer in smaller firms, which may lead to the situation that firm owners care more about their employees' employment security than in large firms. This may be exploited by employees when bargaining about wages and employment at the firm level.

\subsection{Non-Constant Returns to Scale}

In this section, we explore how our results should be interpreted if returns to scale are not constant. In this case, equation (2) is replaced by

$$
\alpha Y=f_{K} K+f_{L} L+f_{I} I
$$

where $\alpha$ is the scale elasticity ( $\alpha<1$ for decreasing, and $\alpha>1$ for increasing returns to scale).

An immediate consequence of (14) is that in the case of decreasing returns, the sum of marginal products does not exhaust the overall product, while in the case of increasing returns, it more than exhausts the overall product. This means that in the case of decreasing returns, at least one factor has to receive more than its marginal product, while in the case of increasing returns at least one factor has to receive less than its marginal product.

The assumption of decreasing or increasing returns to scale modifies our main equation to

$$
\pi=\left(\frac{\text { profit }+ \text { taxes }}{P}\right)=\left(\frac{f_{K}}{\alpha}-\frac{r}{P}\right) K+\left(\frac{f_{L}}{\alpha}-\frac{w}{P}\right) L+\left(\frac{f_{I}}{\alpha}-\frac{q}{P}\right) I .
$$

As a consequence, the interpretation of our estimated coefficients in front of the production factors changes. For example, in the case $\alpha<1$,

$$
\begin{array}{llll}
\left(\frac{f_{K}}{\alpha}-\frac{r}{P}\right)>0 & \Rightarrow & \left(f_{K}-\frac{r}{P}\right) \gtreqless 0 & \text { (indefinite) } \\
\left(\frac{f_{K}}{\alpha}-\frac{r}{P}\right) \leq 0 & \Rightarrow & \left(f_{K}-\frac{r}{P}\right) \leq 0 & \text { (overpayment is underestimated) }
\end{array}
$$

Similarly, in the case $\alpha>1$,

$$
\begin{array}{llll}
\left(\frac{f_{K}}{\alpha}-\frac{r}{P}\right)>0 & \Rightarrow & \left(f_{K}-\frac{r}{P}\right)>0 & \text { (underpayment is underestimated) } \\
\left(\frac{f_{K}}{\alpha}-\frac{r}{P}\right) \leq 0 & \Rightarrow & \left(f_{K}-\frac{r}{P}\right) \gtreqless 0
\end{array}
$$

Decreasing returns to scale at the firm level seem unlikely, for two reasons (see Basu/Fernald $(1995,1997))$. Firstly, the possibility of replication suggests that returns to scale should in general 
not be falling. Secondly, extending the argument in Basu/Fernald $(1995,1997)$ to the case of imperfect input markets (see appendix), one can show that under cost minimization

$$
\mu=\alpha \cdot \frac{\text { revenues }}{\text { costs }+d}
$$

where $\mu$ is the markup-ratio, i.e. the ratio of price to marginal cost, and $d=r^{\prime}(K) K^{2}+$ $w^{\prime}(L) L^{2}+q^{\prime}(I) I^{2} \geq 0$ (because $r^{\prime}(K) \geq 0, w^{\prime}(L) \geq 0, q^{\prime}(I) \geq 0$, see above).

Given information on $\alpha, d$, revenues, and costs, equation (20) implies an estimate for the markupratio. Assuming $d=0$ (no market power in input markets), table 13 shows implied markups for our four subsamples. Basu/Fernald $(1995,1997)$ argue that sharply decreasing returns to scale are implausible because they tend to imply markup-ratios below one (firms price their products below marginal costs, which does not make sense). Equation (20) shows that this is even more severe if firms have market power in input markets, because then implied markups are further depressed (via $d>0$ ). The implied markups in table 13 are therefore upper bounds on actual markups. As one can see, markups tend to be implausibly low - except for large firms - if one assumes decreasing returns to scale $\alpha=0.9$. If $d>0$ (for which we have evidence) they are smaller than one in most cases.

\section{— Table 13 about here -}

As indicated in section 3, there is plenty of evidence in favor of constant returns to scale at the firm level. If however, returns to scale are not exactly constant, the arguments in the previous paragraphs suggest that they are increasing. In this case, equations (18) and (19) show that any underpayment is underestimated, while no definite statement is possible for the case of overpayment. The analysis above also shows (see equation (15)) that for increasing $\alpha$, there is a point from which on all factors will be paid less than their marginal products. The deeper reason for this is that in the case of increasing returns to scale, marginal productivity remunerations add up to more than the overall product, making it necessary that at least one of the factor receives less than its marginal product for high enough $\alpha$.

\section{Conclusion}

In this paper, we have explored a new approach to testing the empirical validity of marginal productivity theory. Our test is based on the fact that under constant returns to scale, firms 
profits are informative about whether individual production factors are over- or underpaid when compared to their marginal products. For our analysis, we do not need to assume any specific parametric form for the production technology. This appears to be a major advantage over previous attempts to test marginal productivity theory as even small amounts of misspecification of the production function may lead to the spurious finding that factor payments do or do not equal marginal products. We also do not make behavioral assumptions such as profit maximization, or assumptions about price taking or price setting behavior. As a consequence, we are able to carry out powerful direct tests of whether such assumptions are consistent with the data. Our analysis also demonstrates that the simplicity of our approach comes at the cost of having to deal with typically highly fat-tailed profit data. We show that this requires the use of robust statistical methods.

Our results using data on manufacturing firms in Chile suggest moderate deviations from marginal productivity theory that also depend on firm size. For small firms, we find that labor input by non-owners is overpaid in some cases, while capital and intermediate inputs tend to be slightly underpaid. The fact that the explicit payments to capital fall short of its marginal product appears to be related to an overpayment of firm owners' labor input, indicating that in small firms the remuneration of firm owners' labor input cannot be separately identified from the remuneration of their capital input. For medium-sized firms we also find that non-owners' labor input is slightly overpaid in some cases, indicating that employees may have a certain degree of bargaining power. One should note however, that in most cases these effects are only marginally significant. Capital is also slightly overpaid in medium-sized firms but only if the residual profits retained in firms are taken into account as a part of capital's remuneration. As in small firms, the contribution of intermediate inputs to output is slightly larger than their costs. The latter is also true for large firms, where the amount of underpayment of intermediate inputs is even larger than in small and medium-sized firms. This suggests that market power in input markets increases with firm size. In large firms, the profits obtained from the underpayment of intermediate inputs solely accrue to capital holders, while the factor labor only receives its marginal product. This indicates that in large firms, employees do not have additional bargaining power. Overall, given that the overpayment of the factor labor that is observed in some cases of small to medium-sized firms is only marginally significant, a fair description of the evidence found is that there are moderate deviations from marginal productivity theory in the form that capital receives more and intermediate inputs receive slightly less than their marginal product. 
We believe that our results provide interesting possibilities for future research. Our empirical application used data for Chile whose economic system is that of a liberal market economy similar to that of the United States. While the results presented here are probably also representative for other countries with similar economic conditions, this is certainly not the case for countries such as those of continental Europe in which trade unions play a much more important role, and market freedom is restricted by a variety of institutional settings. We expect this to have a severe impact on possible deviations of factor payments from marginal products. In any way, it will be interesting to apply the approach described above to other sources on firm data such as those for the U.S. or major European countries. Unfortunately, access to such data sets is still severely restricted. ${ }^{19}$ Depending on the richness of the data available, it will also be interesting to look at higher levels of disaggregation, for example to look at the amount of over- or underpayment of different forms of capital such as equity and external capital, or that of different categories of intermediate inputs.

${ }^{19}$ The need to relax these restrictions is also felt in many other fields of economics, see for example Card (2011). 


\section{References}

Abraham, A. and K. White (2006): The Dynamics of Plant-level Productivity in U.S. Manufacturing, Working Paper 06-20, Center for Economic Studies, U.S. Census Bureau.

Archibald, G.C. (1960): Testing Marginal Productivity Theory, Review of Economic Studies 27, pp. $210-213$.

Arellano, M., and O. Bover (1995): Another look at the instrumental-variable estimation of the error-components models, Journal of Econometrics 68, pp. 29 - 52.

Baily, M.N., Ch. Hulten, and D. Campbell (1992): Productivity Dynamics in Manufacturing Plants, Brookings Papers on Economic Activity: Microeconomics, pp. 187 - 267.

Basu, S. and J.G. Fernald (1995): Are apparent productive spillovers a figment of specification error?, Journal of Monetary Economics 36, pp. 165 - 188.

Basu, S. and J.G. Fernald (1997): Returns to Scale in U.S. Production: Estimates and Implications, Journal of Political Economy 105, pp. 249 - 283.

Basu, S., L. Pascali, F. Schiantarelli and L. Serven (2009): Productivity, Welfare and Reallocation: Theory and Firm-Level Evidence, IZA Discussion Paper No. 4612, Institute for the Study of Labor, Bonn.

Batra, R.N., and A. Ullah (1974): Competitive Firm and the Theory of Input Demand under Price Uncertainty, Journal of Political Economy 82, pp. 537 - 548.

Bhaskar, V., A. Manning, and T. To (2002): Oligopsony and monopsonistic competition in labor markets, Journal of Economic Perspectives 16, pp. 155 - 174.

Blundell, R., and S. Bond (2000): GMM estimation with persistent panel data: an application to production functions, Econometric Reviews 19, pp. 321 - 340.

Bregman, A., M. Fuss and H. Regev (1995): The production and cost structure of Israeli industry from individual firm data, Journal of Econometrics 65, pp. $45-81$.

Bramati, M.C., and C. Croux (2007): Robust estimators for the fixed effects panel data model, Econometrics Journal 10, pp. 521 - 540.

Bronfenbrenner, M., P.H. Douglas (1939): Cross-Section Studies in the Cobb-Douglas Function, 
Journal of Political Economy 157, pp. 761 - 785.

Burnside, C., M. Eichenbaum, and S. Rebelo (1995): Capital Utilization and Returns to Scale, NBER Macroeconomics Annual 10, pp. 67 - 124.

Cahuc, P., and A. Zylberberg (2004): Labor Economics, MIT Press, Cambridge.

Card, D. (2011): The Return of the Firm to Labor Economics, Presidential Address at the Annual Conference of the Society of Labor Economists, April 2011, Vancouver.

Dehon, C., M. Gassner, and V. Verardi (2009): Beware of 'Good' Outliers and Overoptimistic Conclusions, Oxford Bulletin of Economics and Statistics 71, pp. 437 - 452.

Dobbelaere, S., J. Mairesse (2011): Panel Data Estimates of the Production Function and Product and Labor Market Imperfections, forthcoming Journal of Applied Econometrics.

Frank, R.H. (1984): Are Workers Paid their Marginal Products, American Economic Review 74, pp. $549-571$.

Friedman, M. (1976): Price Theory, Aldine Transaction Publishers, Chicago.

Gollin, D. (2002): Getting Income Shares Right, Journal of Political Economy 110, pp. 458 474.

Gottschalk, P.T., J. Tinbergen (1982): Methodological Issues in Testing the Marginal Productivity Theory, De Economist 130, pp. 325 - 335.

Gottschalk, P.T. (1978): A Comparison of Marginal Productivity and Earnings by Occupation, Industrial and Labor Relations Review 31, pp. 368 - 378.

Griliches, Z., J.A. Hausman (1986): Errors in variables in panel data, Journal of Econometrics 31, pp 93 - 118.

Griliches, Z. and V. Ringstad (1971): Economies of scale and the form of the production function, North-Holland, Amsterdam.

Gunn, G.T., P.H. Douglas (1942): The Production Function for American Manufacturing for 1914, Journal of Political Economy 50, pp. 595 - 602.

Gunn, G.T., P.H. Douglas (1942): Further Measurements of Marginal Productivity, Quarterly Journal of Economics 55, pp. 399 - 428. 
Hellerstein, J.K., D. Neumark, and K.R. Troske (1999): Wages, Productivity, and Worker Characteristics: Evidence from Plant-Level Production Functions and Wage Equations, Journal of Labor Economics 17, pp. 409 - 446.

Hellerstein, J.K., D. Neumark (1999): Sex, Wages, and Productivity: An Empirical Analysis of Israeli Firm-Level Data, International Economic Review 40, pp. 95 - 123.

Hildenbrand, G., T.C. Lui (1957): Manufacturing Production Functions in the United States 1957. An Interindustry and Interstate Comparison of Productivity, Cornell University, Ithaca.

Inklaar, R. (2007): Cyclical Productivity in Europe and the United States: Evaluating the Evidence on Returns to Scale and Input Utilization, Economica 74, pp. 822 - 841.

Jann, B. (2010): robreg: Stata module providing robust regression estimators, available from http://ideas.repec.org/c/boc/bocode/s457114.html

Lawrence, S., and Ishikawa, J. (2005): Trade union membership and collective bargaining coverage: Statistical concepts, methods and findings, INTEGRATION Paper No. 59, International Labour Office, Geneva.

Leland, H.E. (1972): Theory of the Firm Facing Uncertain Demand, American Economic Review 62, pp. $278-291$.

Levinsohn, J. and A. Petrin (2003): Estimating Production Functions Using Inputs to Control for Unobservables, Review of Economic Studies 70, pp. 317 - 341.

Levinsohn, J. and A. Petrin (2008): Measuring Aggregate Productivity Growth Using Plant-level Data, Working Paper, University of Minnesota.

Lindbeck, A., and D.J. Snower (1987): Efficiency Wages versus Insiders and Outsiders, European Economic Review 31, pp. 407 - 416.

Lindbeck, A., and D.J. Snower (1988): Cooperation, Harassment, and Involuntary Unemployment: An Insider-Outsider Approach, American Economic Review 78, pp. 167 - 188.

Lui, L. (1993): Entry-Exit, and Learning in the Chilean Manufacturing Sector, Journal of Development Economics 42, pp. 217 - 242.

Manning, A. (2003): Monopsony in motion: imperfect competition in the labor markets, Princeton University Press, Princeton. 
Maronna, R.A., D.R. Martin and V.J. Yohai (2006): Robust Statistics. Theory and Methods, Wiley, Chichester.

McDonald, I.M., and R.M. Solow (1981): Wage bargaining and employment, American Economic Review 71, pp. 896 - 908.

Nguyen, S.V. and A.R. Reznek (1991): Returns to Scale in Small and Large U.S. Manufacturing Establishments, Small Business Economics 3, pp. 197 - 214.

Oulton, N. (1996): Increasing Returns and Externalities in UK Manufacturing: Myth or Reality?, Journal of Industrial Economics 44, pp. 99 - 113.

Pavcnik, N. (2002): Trade Liberalization, Exit, and Productivity Improvements: Evidence from Chilean Plants, Review of Economic Studies 69, pp. 245 - 276.

Solow, R. (1985): Insiders and Outsiders in Wage Determination, Scandinavian Journal of Economics 87, pp. 411 - 428.

Stein, J.L. (1958): The Predictive Accuracy of the Marginal Productivity Theory of Wages, Review of Economic Studies 25, pp. 182 - 189.

Thurow, L.C. (1968): Disequilibrium and the Marginal Productivity of Capital and Labor, Review of Economics and Statistics 50, pp. 23-31.

Verardi, V. and C. Croux (2009): Robust Regression in Stata, The Stata Journal 9, pp. 439 453.

Verardi, V. and J. Wagner (2010): Productivity Premia for German Manufacturing Firms Exporting to the Euro-Area and Beyond: First Evidence from Robust Fixed Effects Estimations, IZA Discussion Paper No. 4964, Institute for the Study of Labor, Bonn.

Westbrook, M.D. and J.R. Tybout (1993): Estimating Returns to Scale with Large, Imperfect Panels: An Application to Chilean Manufacturing Industries, The World Bank Economic Review 7, pp. $85-112$.

Yohai, V.J. (1987): High Breakdown-Point and High Efficiency Robust Estimates for Regression, Annals of Statistics 152, pp. 642 - 656. 


\section{Figures}

Figure 1 - Input and output measures over time, firms with 10 - 1000 workers

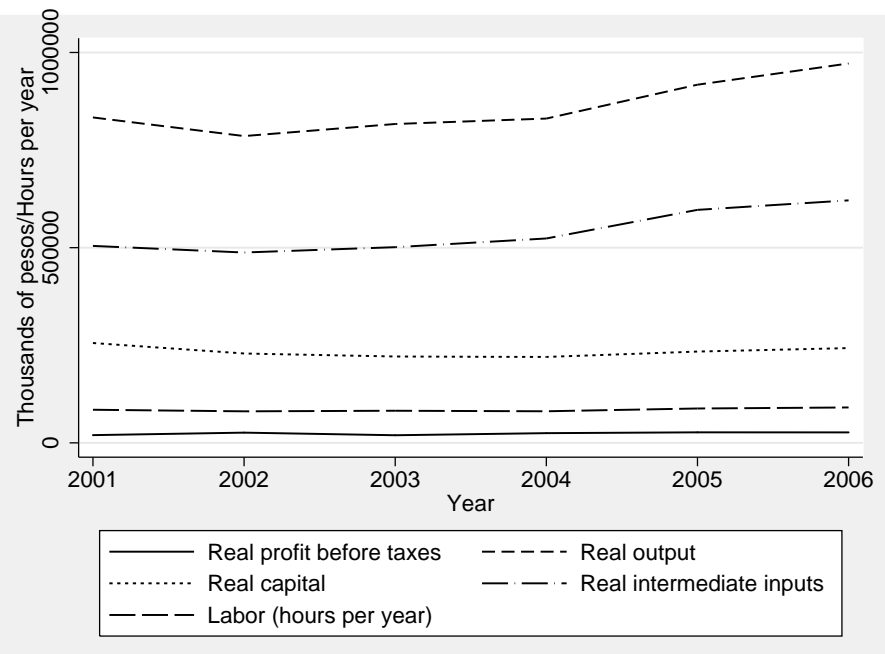

Source: ENIA, own calculations

Figure 2 - Labor input by category, firms with 10 - 1000 workers

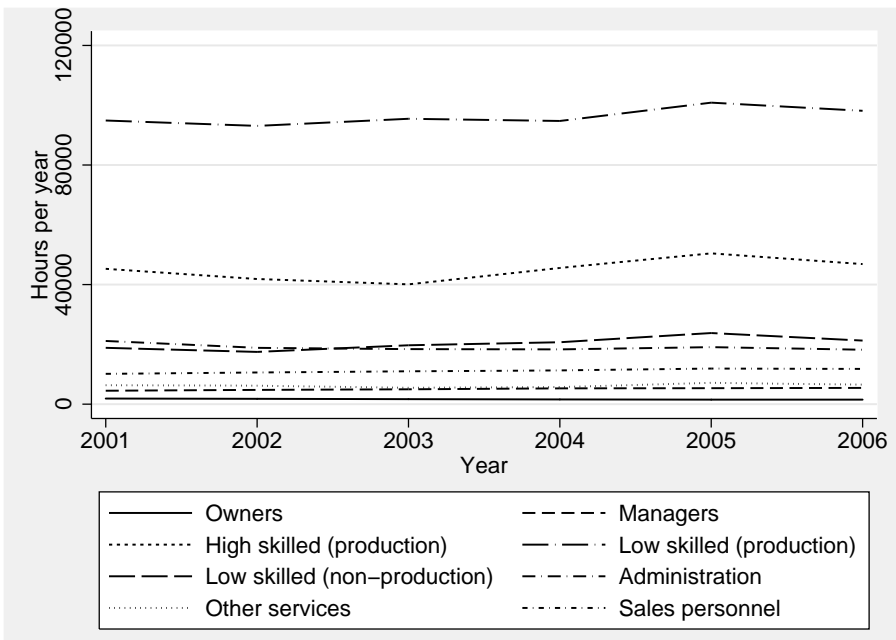

Source: ENIA, own calculations 
Figure 3 - Macro-economic variables for Chile

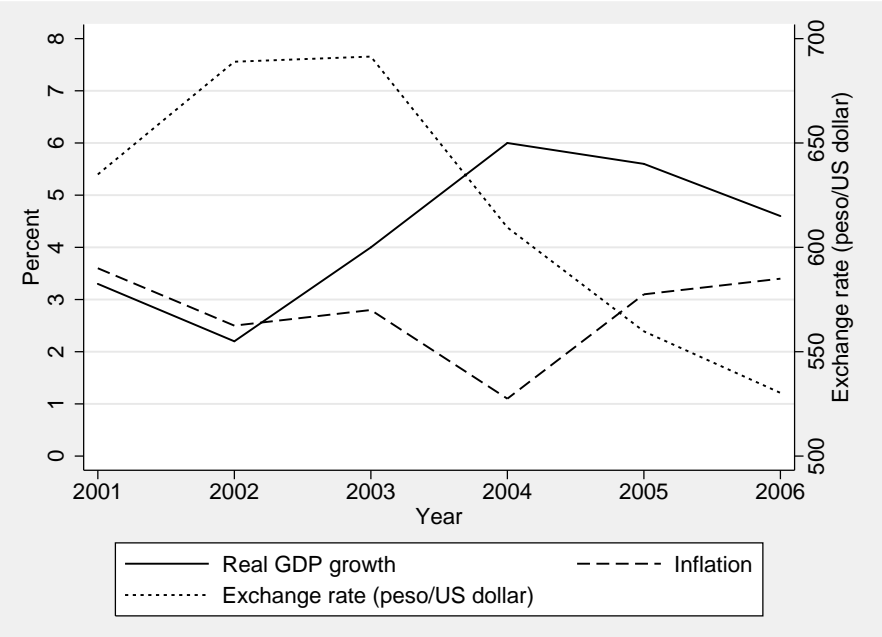

Source: OECD 
Figure 4 - Illustration of 'outlying' observations, firms with 10 - 25 workers
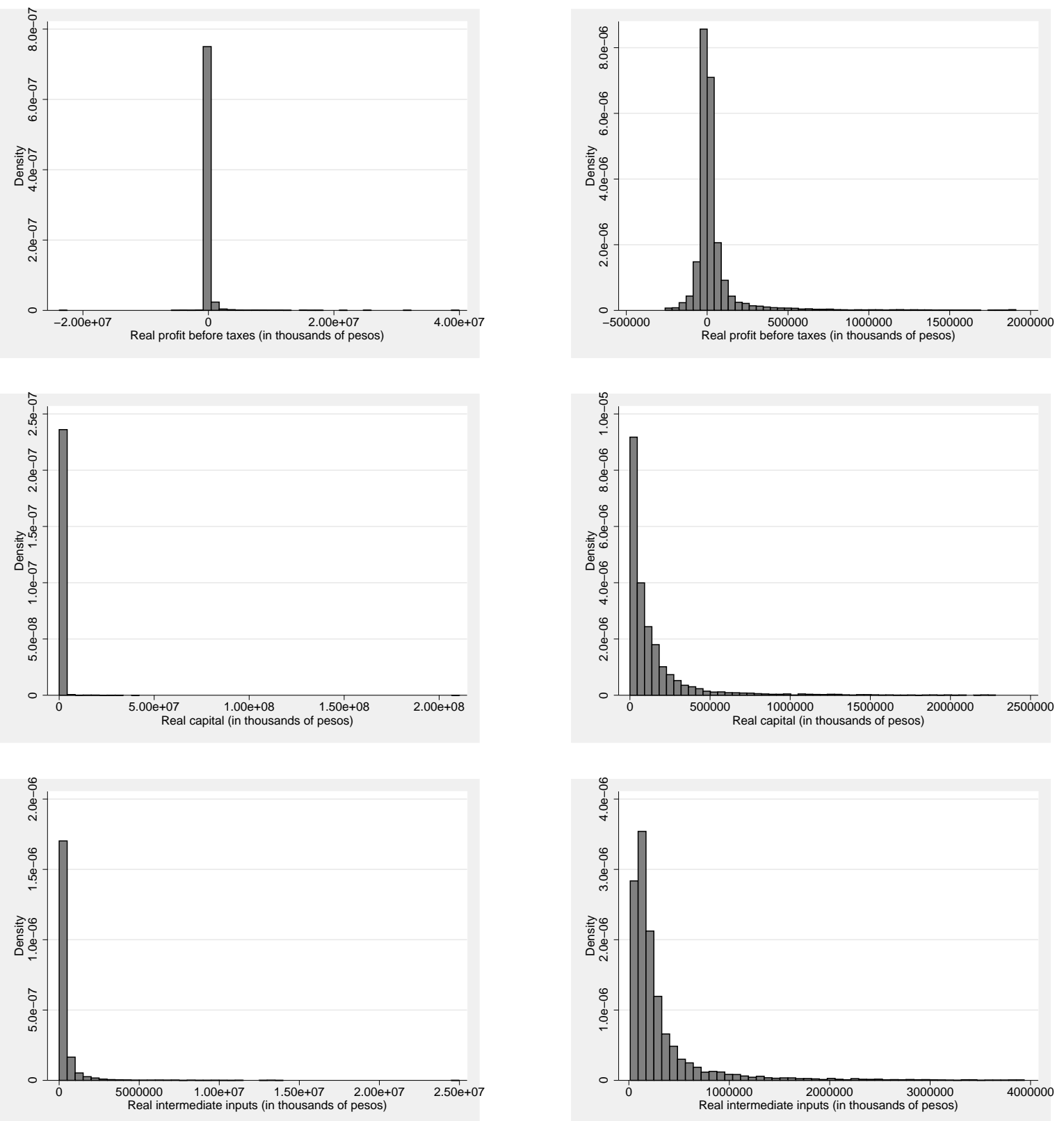

Left hand panel: original sample. Right hand panel: sample after discarding top and bottom $1 \%$. Source: ENIA, own calculations 


\section{Tables}

Table 1 - Robust Regression: Firms with 10-25 workers (7,312/20,448 observations $)^{a}$

\begin{tabular}{|c|c|c|c|c|c|c|}
\hline Real profit before taxes & \multicolumn{2}{|c|}{ Specification 1} & \multicolumn{2}{|c|}{ Specification 2} & \multicolumn{2}{|c|}{ Specification 3} \\
\hline Real capital & .0615 & $(.0137)$ & .0807 & $(.0134)$ & .0806 & $(.0134)$ \\
\hline Real capital (incl. profits) & .1299 & $(.0575)$ & .1491 & $(.0575)$ & .1489 & $(.0574)$ \\
\hline Real intermediate inputs & .0420 & $(.0069)$ & .0417 & $(.0071)$ & .0414 & $(.0074)$ \\
\hline Labor (all categories) & -.1259 & $(.0513)$ & & & & \\
\hline Labor category $1^{b}$ & & & -.7542 & $(.1886)$ & & \\
\hline Labor category 2 & & & -.0763 & $(.0580)$ & & \\
\hline Labor category 3 & & & -.1506 & $(.0741)$ & & \\
\hline Labor category 4 & & & -.1216 & $(.0611)$ & & \\
\hline Owners & & & & & -1.0501 & $(.2601)$ \\
\hline Managers & & & & & -.4319 & $(.2396)$ \\
\hline High-skilled (production) & & & & & -.0563 & $(.0622)$ \\
\hline Low-skilled (production) & & & & & -.1268 & $(.0623)$ \\
\hline Low-skilled (non-production) & & & & & -.0868 & $(.1679)$ \\
\hline Administration & & & & & -.2415 & $(.1316)$ \\
\hline Other services & & & & & .5378 & $(.2934)$ \\
\hline Sales personnel & & & & & -.1655 & $(.0759)$ \\
\hline Constant $^{c}$ & -8479.72 & $(2286.48)$ & -8803.16 & $(2300.33)$ & -8565.38 & $(2356.76)$ \\
\hline
\end{tabular}

Source: ENIA, 2001-2006, own computations.

${ }^{a}$ Bootstrap standard errors accounting for panel structure of the data in parentheses.

${ }^{b}$ Labor category $1=$ Owners, Managers

Labor category 2 = High-skilled (production), Administration

Labor category 3 = Sales personnel

Labor category $4=$ Low-skilled (production and non-production), Other services

${ }^{c}$ Also includes time dummies. Omitting constant and time dummies changes results only marginally. 
Table 2 - Real hourly wages of workers in firms with 10-25 workers, in thousands of pesos ${ }^{a}$

\begin{tabular}{|l|rr|rrrrr|}
\hline & Mean & Std.Dev. & $10 \%$ & $25 \%$ & $50 \%$ & $75 \%$ & $90 \%$ \\
\hline All workers & 2.034 & 1.220 & .956 & 1.204 & 1.700 & 2.468 & 3.46474 \\
\hline Labor category $1^{b}$ & 5.314 & 5.636 & 1.104 & 2.188 & 4.349 & 6.707 & 10.417 \\
Labor category 2 & 2.253 & 3.681 & .928 & 1.230 & 1.777 & 2.661 & 4.016 \\
Labor category 3 & 2.408 & 2.600 & .706 & .932 & 1.442 & 2.901 & 5.275 \\
Labor category 4 & 1.606 & 1.207 & .805 & 1.018 & 1.347 & 1.82 & 2.560 \\
\hline Owners & 4.655 & 5.790 & .955 & 1.812 & 3.759 & 6.327 & 8.637 \\
Managers & 6.017 & 4.933 & 1.372 & 2.552 & 4.759 & 7.753 & 12.386 \\
High-skilled (production) & 2.571 & 4.315 & .960 & 1.283 & 1.892 & 3.038 & 4.907 \\
Low-skilled (production) & 1.656 & 1.372 & .822 & 1.036 & 1.375 & 1.855 & 2.647 \\
Low-skilled (non-production) & 1.772 & 2.363 & .763 & .990 & 1.366 & 2.044 & 2.843 \\
Administration & 2.100 & 1.524 & .871 & 1.164 & 1.704 & 2.596 & 3.735 \\
Other services & 1.449 & 1.218 & .687 & .904 & 1.22 & 1.666 & 2.229 \\
Sales personnel & 2.408 & 2.600 & .706 & .932 & 1.442 & 2.901 & 5.275 \\
\hline
\end{tabular}

Source: ENIA, 2001-2006, own computations.

${ }^{a}$ Nominal wages deflated by CPI (base year 2003).

${ }^{b}$ Labor category $1=$ Owners, Managers

Labor category 2 = High-skilled (production), Administration

Labor category $3=$ Sales personnel

Labor category $4=$ Low-skilled (production and non-production), Other services 
Table 3 - Robust Regression: Firms with $26-100$ workers $(8,446 / 20,448 \text { observations })^{a}$

\begin{tabular}{|c|c|c|c|c|c|c|}
\hline Real profit before taxes & \multicolumn{2}{|c|}{ Specification 1} & \multicolumn{2}{|c|}{ Specification 2} & \multicolumn{2}{|c|}{ Specification 3} \\
\hline Real capital & .0655 & $(.0154)$ & .0653 & $(.0144)$ & .0651 & $(.0149)$ \\
\hline Real capital (incl. profits) & -.1365 & $(.0352)$ & -.1366 & $(.0354)$ & -.1368 & $(.0354)$ \\
\hline Real intermediate inputs & .0522 & $(.0170)$ & .0525 & $(.0158)$ & .0530 & $(.0152)$ \\
\hline Labor (all categories) & -.1985 & $(.0822)$ & & & & \\
\hline Labor category $1^{b}$ & & & -.3689 & $(.5320)$ & & \\
\hline Labor category 2 & & & -.1721 & $(.0880)$ & & \\
\hline Labor category 3 & & & -.3033 & $(.1703)$ & & \\
\hline Labor category 4 & & & -.1938 & $(.0753)$ & & \\
\hline Owners & & & & & -.9555 & $(.7229)$ \\
\hline Managers & & & & & -.0150 & $(.6008)$ \\
\hline High-skilled (production) & & & & & -.1451 & $(.0826)$ \\
\hline Low-skilled (production) & & & & & -.1577 & $(.0718)$ \\
\hline Low-skilled (non-production) & & & & & -.4181 & $(.1437)$ \\
\hline Administration & & & & & -.2687 & $(.2574)$ \\
\hline Other services & & & & & -.3264 & $(.3459)$ \\
\hline Sales personnel & & & & & -.2618 & $(.1534)$ \\
\hline Constant $^{c}$ & -2677.86 & $(5044.95)$ & -2346.24 & $(5043.4)$ & -1768.59 & $(5156.72)$ \\
\hline
\end{tabular}

Source: ENIA, 2001-2006, own computations.

${ }^{a}$ Bootstrap standard errors accounting for panel structure of the data in parentheses.

${ }^{b}$ Labor category $1=$ Owners, Managers

Labor category 2 = High-skilled (production), Administration

Labor category $3=$ Sales personnel

Labor category $4=$ Low-skilled (production and non-production), Other services

${ }^{c}$ Also includes time dummies. Omitting constant and time dummies changes results only marginally. 
Table 4 - Real hourly wages of workers in firms with 26-100 workers, in thousands of pesos ${ }^{a}$

\begin{tabular}{|l|rr|rrrrr|}
\hline & Mean & Std.Dev. & $10 \%$ & $25 \%$ & $50 \%$ & $75 \%$ & $90 \%$ \\
\hline All workers & 2.530 & 1.560 & 1.121 & 1.522 & 2.155 & 3.025 & 4.253 \\
\hline${\text { Labor category } 1^{b}}_{\text {Labor category 2 }}$ & 9.263 & 7.825 & 2.414 & 4.474 & 6.978 & 11.912 & 18.333 \\
Labor category 3 & 2.979 & 1.977 & 1.215 & 1.746 & 2.577 & 3.658 & 5.087 \\
Labor category 4 & 4.105 & 3.708 & 1.005 & 1.625 & 3.100 & 5.380 & 8.402 \\
\hline Owners & 1.850 & 1.308 & .912 & 1.185 & 1.612 & 2.146 & 2.942 \\
Managers & 7.125 & 5.907 & 1.885 & 3.388 & 6.031 & 8.366 & 14.053 \\
High-skilled (production) & 10.368 & 8.476 & 2.758 & 5.026 & 8.131 & 13.381 & 20.083 \\
Low-skilled (production) & 3.594 & 2.841 & 1.263 & 1.859 & 2.889 & 4.540 & 6.579 \\
Low-skilled (non-production) & 1.886 & 1.956 & .900 & 1.177 & 1.585 & 2.149 & 2.954 \\
Administration & 2.247 & 1.735 & .894 & 1.316 & 1.910 & 2.707 & 3.776 \\
Other services & 2.793 & 1.886 & 1.127 & 1.646 & 2.370 & 3.408 & 4.799 \\
Sales personnel & 1.890 & 10.006 & .793 & 1.062 & 1.442 & 2.009 & 2.831 \\
\hline
\end{tabular}

Source: ENIA, 2001-2006, own computations.

${ }^{a}$ Nominal wages deflated by CPI (base year 2003).

${ }^{b}$ Labor category $1=$ Owners, Managers

Labor category 2 = High-skilled (production), Administration

Labor category $3=$ Sales personnel

Labor category $4=$ Low-skilled (production and non-production), Other services 
Table 5 - Robust Regression: Firms with $101-1000$ workers (4,690/20,448 observations) ${ }^{a}$

\begin{tabular}{|c|c|c|c|c|c|c|}
\hline Real profit before taxes & \multicolumn{2}{|c|}{ Specification 1} & \multicolumn{2}{|c|}{ Specification 2} & \multicolumn{2}{|c|}{ Specification 3} \\
\hline Real capital & .1093 & $(.0341)$ & .1073 & $(.0325)$ & .1012 & $(.0321)$ \\
\hline Real capital (incl. profits) & -.3584 & $(.0454)$ & -.3603 & $(.0437)$ & -.3665 & $(.0433)$ \\
\hline Real intermediate inputs & .0892 & $(.0180)$ & .0897 & $(.0172)$ & .1016 & $(.0177)$ \\
\hline Labor (all categories) & .1101 & $(.1551)$ & & & & \\
\hline Labor category $1^{b}$ & & & -3.1273 & $(3.3483)$ & & \\
\hline Labor category 2 & & & .2041 & $(.2760)$ & & \\
\hline Labor category 3 & & & -.5343 & $(.4550)$ & & \\
\hline Labor category 4 & & & .1951 & $(.1774)$ & & \\
\hline Owners & & & & & -11.6090 & $(6.7965)$ \\
\hline Managers & & & & & -1.1584 & $(3.5937)$ \\
\hline High-skilled (production) & & & & & .2467 & $(.2865)$ \\
\hline Low-skilled (production) & & & & & .1266 & $(.1638)$ \\
\hline Low-skilled (non-production) & & & & & .7245 & $(.6058)$ \\
\hline Administration & & & & & -1.6608 & $(1.2318)$ \\
\hline Other services & & & & & 1.1175 & $(2.1841)$ \\
\hline Sales personnel & & & & & -.5502 & $(.4538)$ \\
\hline Constant $^{c}$ & 22475.98 & $(77531.82)$ & 39548.25 & (79342.13) & 72964.82 & $(81931.40)$ \\
\hline
\end{tabular}

Source: ENIA, 2001-2006, own computations.

${ }^{a}$ Bootstrap standard errors accounting for panel structure of the data in parentheses.

${ }^{b}$ Labor category $1=$ Owners, Managers

Labor category 2 = High-skilled (production), Administration

Labor category $3=$ Sales personnel

Labor category $4=$ Low-skilled (production and non-production), Other services

${ }^{c}$ Also includes time dummies. Omitting constant and time dummies changes results only marginally. 
Table 6 - Real hourly wages of workers in firms with 101-1000 workers, in thousands of pesos ${ }^{a}$

\begin{tabular}{|l|rr|rrrrr|}
\hline & Mean & Std.Dev. & $10 \%$ & $25 \%$ & $50 \%$ & $75 \%$ & $90 \%$ \\
\hline All workers & 3.227 & 2.472 & 1.317 & 1.834 & 2.632 & 3.916 & 5.583 \\
\hline Labor category 1 $^{b}$ & 17.115 & 13.264 & 5.331 & 8.681 & 14.726 & 21.873 & 30.140 \\
Labor category 2 & 4.123 & 3.228 & 1.724 & 2.465 & 3.511 & 4.939 & 6.820 \\
Labor category 3 & 6.474 & 9.716 & 1.507 & 2.724 & 5.161 & 8.245 & 11.885 \\
Labor category 4 & 2.419 & 4.787 & .993 & 1.377 & 1.896 & 2.656 & 3.812 \\
\hline Owners & 14.102 & 14.935 & 3.555 & 5.918 & 8.431 & 19.052 & 30.065 \\
Managers & 17.229 & 13.290 & 5.358 & 8.892 & 14.743 & 21.914 & 30.378 \\
High-skilled (production) & 4.875 & 5.206 & 1.718 & 2.558 & 3.901 & 5.811 & 8.480 \\
Low-skilled (production) & 2.562 & 8.277 & .935 & 1.296 & 1.781 & 2.499 & 3.598 \\
Low-skilled (non-production) & 3.119 & 13.707 & 1.120 & 1.672 & 2.419 & 3.484 & 4.752 \\
Administration & 4.002 & 5.141 & 1.586 & 2.299 & 3.281 & 4.629 & 6.443 \\
Other services & 2.211 & 3.019 & .848 & 1.164 & 1.674 & 2.478 & 3.687 \\
Sales personnel & 6.474 & 9.716 & 1.507 & 2.724 & 5.161 & 8.245 & 11.885 \\
\hline
\end{tabular}

Source: ENIA, 2001-2006, own computations.

${ }^{a}$ Nominal wages deflated by CPI (base year 2003).

${ }^{b}$ Labor category $1=$ Owners, Managers

Labor category 2 = High-skilled (production), Administration

Labor category $3=$ Sales personnel

Labor category $4=$ Low-skilled (production and non-production), Other services 
Table 7 - Robust Regression: Firms with 10-1000 workers (total sample, 20,448 observations) ${ }^{a}$

\begin{tabular}{|c|c|c|c|c|c|c|}
\hline Real profit before taxes & \multicolumn{2}{|c|}{ Specification 1} & \multicolumn{2}{|c|}{ Specification 2} & \multicolumn{2}{|c|}{ Specification 3} \\
\hline Real capital & .0781 & $(.0303)$ & .0730 & $(.0242)$ & .0476 & $(.0194)$ \\
\hline Real capital (incl. profits) & -.0890 & $(.0404)$ & -.0940 & $(.0351)$ & -.1194 & $(.0332)$ \\
\hline Real intermediate inputs & .0299 & $(.0164)$ & .0565 & $(.0143)$ & .0360 & $(.0131)$ \\
\hline Labor (all categories) & -.1009 & $(.0660)$ & & & & \\
\hline Labor category $1^{b}$ & & & -.8582 & $(.4294)$ & & \\
\hline Labor category 2 & & & -.1952 & $(.0818)$ & & \\
\hline Labor category 3 & & & -.1645 & $(.1315)$ & & \\
\hline Labor category 4 & & & -.1470 & $(.0583)$ & & \\
\hline Owners & & & & & -.9578 & $(.3816)$ \\
\hline Managers & & & & & -.0704 & $(.4550)$ \\
\hline High-skilled (production) & & & & & -.0659 & $(.0709)$ \\
\hline Low-skilled (production) & & & & & -.0407 & $(.0501)$ \\
\hline Low-skilled (non-production) & & & & & -.0864 & $(.1408)$ \\
\hline Administration & & & & & -.1302 & $(.3252)$ \\
\hline Other services & & & & & -.0690 & $(.3706)$ \\
\hline Sales personnel & & & & & -.1218 & $(.1220)$ \\
\hline Constant $^{c}$ & -7168.47 & $(2967.40)$ & -7429.12 & $(2765.92)$ & -4380.57 & $(2834.51)$ \\
\hline
\end{tabular}

Source: ENIA, 2001-2006, own computations.

${ }^{a}$ Bootstrap standard errors accounting for panel structure of the data in parentheses.

${ }^{b}$ Labor category $1=$ Owners, Managers

Labor category 2 = High-skilled (production), Administration

Labor category $3=$ Sales personnel

Labor category $4=$ Low-skilled (production and non-production), Other services

${ }^{c}$ Also includes time dummies. Omitting constant and time dummies changes results only marginally. 
Table 8 - Real hourly wages of workers in firms with 10-1000 workers, in thousands of pesos ${ }^{a}$

\begin{tabular}{|l|rr|rrrrr|}
\hline & Mean & Std.Dev. & $10 \%$ & $25 \%$ & $50 \%$ & $75 \%$ & $90 \%$ \\
\hline All workers & 2.512 & 1.771 & 1.056 & 1.426 & 2.083 & 3.027 & 4.360 \\
\hline Labor category 1 $^{b}$ & 9.931 & 10.003 & 1.881 & 3.934 & 6.872 & 13.113 & 21.034 \\
Labor category 2 & 3.011 & 3.033 & 1.095 & 1.599 & 2.476 & 3.727 & 5.32337 \\
Labor category 3 & 4.175 & 5.792 & .870 & 1.374 & 2.829 & 5.523 & 8.9312 \\
Labor category 4 & 1.912 & 2.644 & .884 & 1.150 & 1.582 & 2.177 & 3.059 \\
\hline Owners & 6.914 & 8.127 & 1.261 & 2.769 & 5.457 & 7.629 & 13.898 \\
Managers & 11.628 & 10.675 & 2.470 & 4.883 & 8.732 & 15.531 & 23.546 \\
High-skilled (production) & 3.637 & 4.141 & 1.155 & 1.719 & 2.790 & 4.538 & 6.803 \\
Low-skilled (production) & 1.985 & 4.454 & .878 & 1.146 & 1.559 & 2.151 & 3.039 \\
Low-skilled (non-production) & 2.463 & 8.357 & .891 & 1.288 & 1.953 & 2.871 & 4.067 \\
Administration & 2.894 & 3.090 & 1.038 & 1.541 & 2.369 & 3.541 & 5.062 \\
Other services & 1.910 & 7.028 & .779 & 1.051 & 1.462 & 2.080 & 3.048 \\
Sales personnel & 4.175 & 5.792 & .870 & 1.374 & 2.829 & 5.523 & 8.931 \\
\hline
\end{tabular}

Source: ENIA, 2001-2006, own computations.

${ }^{a}$ Nominal wages deflated by CPI (base year 2003).

${ }^{b}$ Labor category $1=$ Owners, Managers

Labor category 2 = High-skilled (production), Administration

Labor category $3=$ Sales personnel

Labor category $4=$ Low-skilled (production and non-production), Other services 
Table 9 - Fixed effects on robust subsample: Firms with 10-25 workers ${ }^{a}$

\begin{tabular}{|c|c|c|c|c|c|c|}
\hline Real profit before taxes & \multicolumn{2}{|c|}{ Specification 1} & \multicolumn{2}{|c|}{ Specification 2} & \multicolumn{2}{|c|}{ Specification 3} \\
\hline Real capital & .0318 & $(.0137)$ & .0521 & $(.0137)$ & .0534 & $(.0136)$ \\
\hline Real capital (incl. profits) & .1002 & $(.0532)$ & .1205 & $(.0532)$ & .1218 & $(.0531)$ \\
\hline Real intermediate inputs & .0091 & $(.0118)$ & .0153 & $(.0118)$ & .0138 & $(.0118)$ \\
\hline Labor (all categories) & -.0928 & $(.0728)$ & & & & \\
\hline Labor category $1^{b}$ & & & -.4767 & $(.2216)$ & & \\
\hline Labor category 2 & & & -.0453 & $(.0918)$ & & \\
\hline Labor category 3 & & & -.1688 & $(.1269)$ & & \\
\hline Labor category 4 & & & -.0720 & $(.0805)$ & & \\
\hline Owners & & & & & -.8744 & $(.3545)$ \\
\hline Managers & & & & & -.2096 & $(.2801)$ \\
\hline High-skilled (production) & & & & & -.0074 & $(.0989)$ \\
\hline Low-skilled (production) & & & & & -.0693 & $(.0864)$ \\
\hline Low-skilled (non-production) & & & & & -.0110 & $(.1541)$ \\
\hline Administration & & & & & -.2390 & $(.2030)$ \\
\hline Other services & & & & & .5675 & $(.2756)$ \\
\hline Sales personnel & & & & & -.1213 & $(.1312)$ \\
\hline Constant $^{c}$ & 3261.61 & $(3924.11)$ & 716.92 & $(3984.59)$ & 816.19 & $(3975.64)$ \\
\hline Size robust subsample & & 6,112 & & 6,114 & & 6,113 \\
\hline
\end{tabular}

Source: ENIA, 2001-2006, own computations.

${ }^{a}$ Bootstrap standard errors accounting for panel structure of the data in parentheses.

${ }^{b}$ Labor category $1=$ Owners, Managers

Labor category 2 = High-skilled (production), Administration

Labor category $3=$ Sales personnel

Labor category $4=$ Low-skilled (production and non-production), Other services

${ }^{c}$ Also includes time dummies. Omitting constant and time dummies changes results only marginally. 
Table 10 - Fixed effects on robust subsample: Firms with 26-100 workers $^{a}$

\begin{tabular}{|c|c|c|c|c|c|c|}
\hline Real profit before taxes & \multicolumn{2}{|c|}{ Specification 1} & \multicolumn{2}{|c|}{ Specification 2} & \multicolumn{2}{|c|}{ Specification 3} \\
\hline Real capital & .0386 & $(.0097)$ & .0387 & $(.0097)$ & .0399 & $(.0098)$ \\
\hline Real capital (incl. profits) & -.1633 & $(.0293)$ & -.1632 & $(.0293)$ & -.1620 & $(.0293)$ \\
\hline Real intermediate inputs & .0198 & $(.0099)$ & .0204 & $(.0099)$ & .0202 & $(.0100)$ \\
\hline Labor (all categories) & -.1366 & $(.0655)$ & & & & \\
\hline Labor category $1^{b}$ & & & -.2139 & $(.4835)$ & & \\
\hline Labor category 2 & & & -.1880 & $(.0958)$ & & \\
\hline Labor category 3 & & & -.6575 & $(.2205)$ & & \\
\hline Labor category 4 & & & -.0699 & $(.0735)$ & & \\
\hline Owners & & & & & .0278 & $(1.0873)$ \\
\hline Managers & & & & & -.1860 & $(.5229)$ \\
\hline High-skilled (production) & & & & & -.2197 & $(.1083)$ \\
\hline Low-skilled (production) & & & & & -.0495 & $(.0827)$ \\
\hline Low-skilled (non-production) & & & & & -.0165 & $(.1864)$ \\
\hline Administration & & & & & .0210 & $(.2762)$ \\
\hline Other services & & & & & -.6428 & $(.4390)$ \\
\hline Sales personnel & & & & & -.6725 & $(.2166)$ \\
\hline Constant $^{c}$ & 37244.10 & $(10066.03)$ & 37905.82 & $(10219.55)$ & 35378.55 & $(10575.29)$ \\
\hline Size robust subsample & & 6,759 & & 6,759 & & 6,753 \\
\hline
\end{tabular}

Source: ENIA, 2001-2006, own computations.

${ }^{a}$ Bootstrap standard errors accounting for panel structure of the data in parentheses.

${ }^{b}$ Labor category $1=$ Owners, Managers

Labor category 2 = High-skilled (production), Administration

Labor category $3=$ Sales personnel

Labor category $4=$ Low-skilled (production and non-production), Other services

${ }^{c}$ Also includes time dummies. Omitting constant and time dummies changes results only marginally. 
Table 11 - Fixed effects on robust subsample: Firms with 101-1000 workers $^{a}$

\begin{tabular}{|c|c|c|c|c|c|c|}
\hline Real profit before taxes & \multicolumn{2}{|c|}{ Specification 1} & \multicolumn{2}{|c|}{ Specification 2} & \multicolumn{2}{|c|}{ Specification 3} \\
\hline Real capital & .0755 & $(.0129)$ & .0774 & $(.0135)$ & .0826 & $(.0138)$ \\
\hline Real capital (incl. profits) & -.3921 & $(.0290)$ & -.3902 & $(.0293)$ & -.3850 & $(.0295)$ \\
\hline Real intermediate inputs & -.0071 & $(.0142)$ & -.0047 & $(.0147)$ & -.0006 & $(.0145)$ \\
\hline Labor (all categories) & .1494 & $(.1491)$ & & & & \\
\hline Labor category $1^{b}$ & & & -4.1866 & $(3.8176)$ & & \\
\hline Labor category 2 & & & .2343 & $(.2773)$ & & \\
\hline Labor category 3 & & & .1207 & $(.6370)$ & & \\
\hline Labor category 4 & & & .1827 & $(.1797)$ & & \\
\hline Owners & & & & & -28.1480 & $(17.7654)$ \\
\hline Managers & & & & & -.3637 & (3.5978) \\
\hline High-skilled (production) & & & & & .2763 & $(.3115)$ \\
\hline Low-skilled (production) & & & & & .1396 & $(.2006)$ \\
\hline Low-skilled (non-production) & & & & & .2318 & $(.5428)$ \\
\hline Administration & & & & & -1.5028 & $(.8011)$ \\
\hline Other services & & & & & 1.0700 & $(1.4390)$ \\
\hline Sales personnel & & & & & .1914 & $(.6691)$ \\
\hline Constant $^{c}$ & $8.7 e+05$ & $(1.4 e+05)$ & $8.7 e+05$ & $(1.4 e+05)$ & $8.5 e+05$ & $(1.5 e+05)$ \\
\hline Size robust subsample & & 3,645 & & 3,645 & & 3,646 \\
\hline
\end{tabular}

Source: ENIA, 2001-2006, own computations.

${ }^{a}$ Bootstrap standard errors accounting for panel structure of the data in parentheses.

${ }^{b}$ Labor category $1=$ Owners, Managers

Labor category 2 = High-skilled (production), Administration

Labor category $3=$ Sales personnel

Labor category $4=$ Low-skilled (production and non-production), Other services

${ }^{c}$ Also includes time dummies. Omitting constant and time dummies changes results only marginally. 
Table 12 - Fixed effects on robust subsample: Firms with 10-1000 workers $^{a}$

\begin{tabular}{|c|c|c|c|c|c|c|}
\hline Real profit before taxes & \multicolumn{2}{|c|}{ Specification 1} & \multicolumn{2}{|c|}{ Specification 2} & \multicolumn{2}{|c|}{ Specification 3} \\
\hline Real capital & .0588 & $(.0048)$ & .0537 & $(.0048)$ & .0374 & $(.0046)$ \\
\hline Real capital (incl. profits) & -.1083 & $(.0301)$ & -.1133 & $(.0300)$ & -.1296 & $(.0301)$ \\
\hline Real intermediate inputs & .0188 & $(.0045)$ & .0376 & $(.0050)$ & .0246 & $(.0047)$ \\
\hline Labor (all categories) & -.0587 & $(.0310)$ & & & & \\
\hline Labor category $1^{b}$ & & & -.2866 & $(.3576)$ & & \\
\hline Labor category 2 & & & -.1832 & $(.0446)$ & & \\
\hline Labor category 3 & & & -.2091 & $(.0949)$ & & \\
\hline Labor category 4 & & & -.0599 & $(.0256)$ & & \\
\hline Owners & & & & & -.2707 & $(.6022)$ \\
\hline Managers & & & & & -.1273 & $(.4199)$ \\
\hline High-skilled (production) & & & & & -.0671 & $(.0583)$ \\
\hline Low-skilled (production) & & & & & -.0035 & $(.0340)$ \\
\hline Low-skilled (non-production) & & & & & -.0212 & $(.1055)$ \\
\hline Administration & & & & & -.4517 & $(.1848)$ \\
\hline Other services & & & & & .0957 & $(.2488)$ \\
\hline Sales personnel & & & & & -.2054 & $(.1089)$ \\
\hline Constant $^{c}$ & 13891.64 & $(4818.77)$ & 16111.7 & $(4486.62)$ & 14918.70 & $(5318.08)$ \\
\hline Size robust subsample & & 14,888 & & 14,882 & & 14,867 \\
\hline
\end{tabular}

Source: ENIA, 2001-2006, own computations.

${ }^{a}$ Bootstrap standard errors accounting for panel structure of the data in parentheses.

${ }^{b}$ Labor category $1=$ Owners, Managers

Labor category 2 = High-skilled (production), Administration

Labor category $3=$ Sales personnel

Labor category $4=$ Low-skilled (production and non-production), Other services

${ }^{c}$ Also includes time dummies. Omitting constant and time dummies changes results only marginally. 
Table 13 - Implied markups assuming no market power in input markets

\begin{tabular}{|l|r|r|r|}
\hline Firm size & $\alpha=0.9$ & $\alpha=1.0$ & $\alpha=1.1$ \\
\hline 10 to 25 workers & .972 & 1.081 & 1.189 \\
26 to 100 workers & 1.000 & 1.112 & 1.223 \\
101 to 1000 workers & 1.122 & 1.246 & 1.371 \\
10 to 1000 workers & 1.018 & 1.131 & 1.245 \\
\hline
\end{tabular}

Source: ENIA, 2001-2006, own computations. 


\section{Appendix}

In this appendix, we extend the relationship between returns to scale $\alpha$ and the markup $\mu$ described in Basu/Fernald (1995) to the case of imperfect input markets.

Assume that firms are cost minimizers, i.e. they solve the minimization problem

$$
\min _{K, L, I} r(K) K+w(L) L+q(I) I \quad \text { s.t. } \quad Y=f(K, L, I)
$$

The Lagrangian is

$$
\mathcal{L}=r(K) K+w(L) L+q(I) I-\lambda(f(K, L, I)-Y)
$$

The markup is defined by $\mu=P / M C$ (with marginal cost $M C$ ). Minimization implies

$$
\begin{aligned}
& M C=\frac{\mathrm{d}\left\{r\left(K^{*}\right) K^{*}+w\left(L^{*}\right) L^{*}+q\left(I^{*}\right) I^{*}\right\}}{\mathrm{d} Y}=\lambda \\
& \frac{\partial \mathcal{L}}{\partial K}=r^{\prime}(K) K+r(K)-\lambda f_{K}=0 \quad \Leftrightarrow \quad f_{K}=\frac{r^{\prime}(K) K+r(K)}{P} \mu \\
& \frac{\partial \mathcal{L}}{\partial L}=w^{\prime}(L) L+w(L)-\lambda f_{L}=0 \quad \Leftrightarrow \quad f_{L}=\frac{w^{\prime}(L) L+w(L)}{P} \mu \\
& \frac{\partial \mathcal{L}}{\partial I}=q^{\prime}(I) I+q(I)-\lambda f_{I}=0 \quad \Leftrightarrow \quad f_{I}=\frac{q^{\prime}(I) I+q(I)}{P} \mu,
\end{aligned}
$$

where stars indicate optimal values.

Under non-constant returns to scale and using the first-order conditions,

$$
\begin{aligned}
\alpha & =\frac{f_{K} K}{Y}+\frac{f_{L} L}{Y}+\frac{f_{I} I}{Y} \\
& =\frac{\left(r^{\prime}(K) K+r\right) K}{P Y} \mu+\frac{\left(w^{\prime}(L) L+w\right) L}{P Y} \mu+\frac{\left(q^{\prime}(I) I+q\right) I}{P Y} \mu \\
& \Longleftrightarrow \quad \mu=\alpha \cdot \frac{P Y}{(r K+w L+q I)+d}=\alpha \cdot \frac{\text { revenues }}{\text { costs }+d},
\end{aligned}
$$

where $d=r^{\prime}(K) K^{2}+w^{\prime}(L) L^{2}+q^{\prime}(I) I^{2} \geq 0$. 
Table 14 - Summary Statistics: Firms with 10-25 workers, in thousands of pesos or hours per year $(7,312 / 20,448$ observations $)$

\begin{tabular}{|c|c|c|c|c|c|c|c|c|c|}
\hline & Mean & Std.Dev. & $10 \%$ & $25 \%$ & $50 \%$ & $75 \%$ & $90 \%$ & Kurtosis & Skewness \\
\hline Real profit before taxes & 101032.0 & $1.1 \mathrm{e}+06$ & -45909.9 & -16215.8 & 2283.65 & 37126.5 & 128860.0 & 584.4 & 18.0 \\
\hline Real profit & 94348.1 & $1.1 \mathrm{e}+06$ & -49626.6 & -19353.5 & -1098.15 & 30824.1 & 117192.0 & 585.1 & 18.0 \\
\hline Real capital & 244825.0 & $2.7 e+06$ & 5931.9 & 19548.2 & 57768.0 & 154318.0 & 340110.0 & 4904.5 & 64.7 \\
\hline Real intermediate inputs & 382911.0 & 915872.0 & 57378.5 & 98479.0 & 170529.0 & 322419.0 & 716328.0 & 144.8 & 9.6 \\
\hline Labor (all categories) & 39679.7 & 11992.5 & 25987 & 30919 & 38536 & 47711 & 54300 & 19.7 & 1.65 \\
\hline Labor category 1 & 3100.4 & 2964.5 & 0 & 0 & 2360 & 4608 & 6912 & 17.7 & 2.1 \\
\hline Labor category 2 & 14174.2 & 13738.1 & 0 & 4088 & 9216 & 22536 & 34560 & 5.8 & 1.3 \\
\hline Labor category 3 & 3299.8 & 6116.7 & 0 & 0 & 0 & 4320 & 11460 & 12.7 & 2.7 \\
\hline Labor category 4 & 19105.3 & 14981.1 & 0 & 4608 & 19200 & 29952 & 38880 & 3.6 & .5 \\
\hline Owners & 1763.9 & 2340.7 & 0 & 0 & 0 & 2558 & 4680 & 8.0 & 1.6 \\
\hline Managers & 1336.4 & 2309.4 & 0 & 0 & 0 & 2304 & 4419 & 34.6 & 3.7 \\
\hline High-skilled (production) & 10422.7 & 13263.5 & 0 & 0 & 4093 & 18432 & 30800 & 5.5 & 1.4 \\
\hline Low-skilled (production) & 16013.5 & 14462.7 & 0 & 0 & 15333.5 & 26400 & 35570 & 3.2 & 6 \\
\hline Low-skilled (non-production) & 1996.7 & 5156.6 & 0 & 0 & 0 & 2160 & 6480 & 40.8 & 5.0 \\
\hline Administration & 3751.5 & 4356.5 & 0 & 0 & 2400 & 4992 & 8640 & 23.6 & 3.1 \\
\hline Other services & 938.0 & 2403.2 & 0 & 0 & 0 & 0 & 2912 & 43.7 & 4.9 \\
\hline Sales personnel & 3299.8 & 6116.77 & 0 & 0 & 0 & 4320 & 11460 & 12.7 & 2.7 \\
\hline
\end{tabular}

Source: ENIA, 2001-2006, own computations. For the definition of labor categories, see table 1. 
Table 15 - Summary Statistics: Firms with 26-100 workers, in thousands of pesos or hours per year $(8,446 / 20,448$ observations)

\begin{tabular}{|c|c|c|c|c|c|c|c|c|c|}
\hline & Mean & Std.Dev. & $10 \%$ & $25 \%$ & $50 \%$ & $75 \%$ & $90 \%$ & Kurtosis & Skewness \\
\hline Real profit before taxes & 465591.0 & $3.5 e+06$ & -114929.0 & -27595.8 & 32173.6 & 187526.0 & 787833.0 & 1031.4 & 26.0 \\
\hline Real profit & 436108.0 & $3.4 \mathrm{e}+06$ & -127688.0 & -36881.3 & 19511.1 & 162020 & 719547 & 1080.1 & 26.4 \\
\hline Real capital & $1.1 \mathrm{e}+06$ & $5.0 e+06$ & 29778.0 & 98197.7 & 297107.0 & 774899.0 & $1.8 \mathrm{e}+06$ & 197.6 & 12.9 \\
\hline Real intermediate inputs & $1.8 e+06$ & $1.1 e+07$ & 181076.0 & 318143.0 & 624617.0 & $1.5 e+06$ & $3.4 e+06$ & 1621.5 & 37.3 \\
\hline Labor (all categories) & 116194.0 & 54379.5 & 62640 & 75134 & 101737 & 147175 & 192339 & 16.9 & 2.0 \\
\hline Labor category 1 & 5401.7 & 5256.0 & 0 & 2204 & 4608 & 7227 & 11424 & 51.9 & 4.0 \\
\hline Labor category 2 & 35584.9 & 38035.3 & 4912 & 11014 & 21600 & 48384 & 84693 & 9.97 & 2.24 \\
\hline Labor category 3 & 7214.3 & 7214.3 & 0 & 0 & 2160 & 9216 & 20736 & 22.6 & 3.6 \\
\hline Labor category 4 & 67992.7 & 67992.7 & 2496 & 32975 & 60240 & 95616 & 136710 & 12.7 & 1.6 \\
\hline Owners & 1885.6 & 2827.7 & 0 & 0 & 0 & 3240 & 5664 & 7.3 & 1.8 \\
\hline Managers & 3516.1 & 4906.6 & 0 & 0 & 2297 & 4858 & 9036 & 63.4 & 4.7 \\
\hline High-skilled (production) & 23540.8 & 35319.1 & 0 & 2400 & 8318 & 29400 & 69120 & 11.9 & 2.6 \\
\hline Low-skilled (production) & 54564.1 & 47854.0 & 0 & 16200 & 48384 & 80096 & 117000 & 12.8 & 1.6 \\
\hline Low-skilled (non-production) & 8970.6 & 17570.8 & 0 & 0 & 2304 & 10800 & 26064 & 81.9 & 5.8 \\
\hline Administration & 12044.1 & 13190.6 & 1150 & 4482 & 8657 & 15795 & 25596 & 31.5 & 3.8 \\
\hline Other services & 3887.6 & 7766.2 & 0 & 0 & 0 & 4819 & 11520 & 65.4 & 5.7 \\
\hline Sales personnel & 7214.3 & 13193.8 & 0 & 0 & 2160 & 9216 & 20736 & 22.6 & 3.6 \\
\hline
\end{tabular}

Source: ENIA, 2001-2006, own computations. For the definition of labor categories, see table 1. 
Table 16 - Summary Statistics: Firms with 101-1000 workers, in thousands of pesos or hours per year (4,690/20,448 observations)

\begin{tabular}{|c|c|c|c|c|c|c|c|c|c|}
\hline & Mean & Std.Dev. & $10 \%$ & $25 \%$ & $50 \%$ & $75 \%$ & $90 \%$ & Kurtosis & Skewness \\
\hline Real profit before taxes & $5.6 e+06$ & $2.5 e+07$ & -422569 & 16999.4 & 707557 & $3.4 \mathrm{e}+06$ & $1.1 \mathrm{e}+07$ & 1031.4 & 26.0 \\
\hline Real profit & $5.3 e+06$ & $2.4 e+07$ & -498854 & -17353.9 & 603560 & $3.2 e+06$ & $1.1 \mathrm{e}+07$ & 1080.1 & 26.4 \\
\hline Real capital & $1.1 e+07$ & $4.3 e+07$ & 294121 & 945209 & $2.7 e+06$ & $7.8 e+06$ & $2.0 e+07$ & 197.6 & 12.9 \\
\hline Real intermediate inputs & $1.6 \mathrm{e}+07$ & $5.2 e+07$ & $1.0 e+06$ & $2.2 \mathrm{e}+06$ & $5.4 e+06$ & $1.3 e+07$ & $2.9 e+07$ & 1621.5 & 37.3 \\
\hline Labor (all categories) & 623294.0 & 490349.0 & 250400 & 310149 & 455308 & 768145 & $1.2 \mathrm{e}+06$ & 16.9 & 2.0 \\
\hline Labor category 1 & 14752.8 & 21731.0 & 0 & 4050 & 9216 & 17470 & 33607 & 51.9 & 4.0 \\
\hline Labor category 2 & 192855.0 & 325197.0 & 24096 & 46100 & 99664 & 216080 & 432615 & 9.9 & 2.2 \\
\hline Labor category 3 & 30474.8 & 88838.8 & 0 & 0 & 2260 & 21168 & 73815 & 22.6 & 3.6 \\
\hline Labor category 4 & 385211.0 & 363274.0 & 66951 & 168480 & 277206 & 479574 & 827136 & 12.7 & 1.6 \\
\hline Owners & 1064.5 & 2712.5 & 0 & 0 & 0 & 0 & 4608 & 7.3 & 1.8 \\
\hline Managers & 13688.3 & 21426.7 & 0 & 2376 & 7879 & 16128 & 32256 & 63.4 & 4.7 \\
\hline High-skilled (production) & 137743.0 & 305993.0 & 6384 & 15462 & 43220 & 138000 & 347057 & 11.9 & 2.6 \\
\hline Low-skilled (production) & 296312.0 & 313026.0 & 0 & 98784 & 211632 & 374000 & 673936 & 12.8 & 1.6 \\
\hline Low-skilled (non-production) & 69482.5 & 129736.0 & 0 & 6900 & 30066.5 & 78639 & 162926 & 81.9 & 5.8 \\
\hline Administration & 55112.3 & 71508.7 & 6238 & 16891 & 34944 & 66816 & 120692 & 31.5 & 3.8 \\
\hline Other services & 18702.9 & 42184.3 & 0 & 0 & 5470 & 20700 & 48384 & 65.4 & 5.7 \\
\hline Sales personnel & 30474.8 & 88838.8 & 0 & 0 & 2260 & 21168 & 73815 & 22.6 & 3.6 \\
\hline
\end{tabular}

Source: ENIA, 2001-2006, own computations. For the definition of labor categories, see table 1. 
Table 17 - Summary Statistics: Firms with 10-1000 workers, in thousands of pesos or hours per year (total sample, 20,448 observations)

\begin{tabular}{|l|rr|rrrrr|rr|}
\hline & Mean & Std.Dev. & $10 \%$ & $25 \%$ & $50 \%$ & $75 \%$ & $90 \%$ & Kurtosis & Skewness \\
\hline Real profit before taxes & $1.5 \mathrm{e}+06$ & $1.2 \mathrm{e}+07$ & -102467 & -18787 & 24128.5 & 265862 & $2.0 \mathrm{e}+06$ & 475.5 & 18.4 \\
Real profit & $1.4 \mathrm{e}+06$ & $1.2 \mathrm{e}+07$ & -120367 & -25319.2 & 15129.4 & 228538 & $1.8 \mathrm{e}+06$ & 479.2 & 18.2 \\
Real capital & $3.2 \mathrm{e}+06$ & $2.1 \mathrm{e}+07$ & 14767.3 & 54714.1 & 231852 & $1.1 \mathrm{e}+06$ & $4.5 \mathrm{e}+06$ & 1674.7 & 31.0 \\
Real intermediate inputs & $4.5 \mathrm{e}+06$ & $2.7 \mathrm{e}+07$ & 97333.1 & 195182 & 538857 & $2.2 \mathrm{e}+06$ & $8.2 \mathrm{e}+06$ & 876.0 & 25.4 \\
Labor (all categories) & 205143.0 & 331024.0 & 31705 & 45053 & 84336 & 207136 & 517875 & 86.0 & 5.3 \\
\hline Labor category 1 & 6723.6 & 11960.4 & 0 & 2160 & 4320 & 7527 & 13824 & 16.6 & 16.6 \\
Labor category 2 & 64000.6 & 173051.0 & 2708 & 8640 & 22362 & 55200 & 138240 & 969.2 & 19.5 \\
Labor category 3 & 11149.6 & 44824.9 & 0 & 0 & 0 & 8640 & 22464 & 246.0 & 13.0 \\
Labor category 4 & 123269.0 & 228754.0 & 0 & 17640 & 44836 & 122104 & 312983 & 27.9 & 4.3 \\
\hline Owners & 1653.7 & 2656.1 & 0 & 0 & 0 & 2400 & 4800 & 15.1 & 2.4 \\
Managers & 5069.8 & 11838.6 & 0 & 0 & 2218 & 5684 & 11616 & 688.6 & 15.3 \\
High-skilled (production) & 45043.6 & 156974.0 & 0 & 2304 & 10122 & 34024 & 91632 & 1394.7 & 24.3 \\
Low-skilled (production) & 96226.6 & 188922.0 & 0 & 8640 & 33866 & 93142 & 243192 & 30.3 & 4.5 \\
Low-skilled (non-production) & 20356.0 & 68735.3 & 0 & 0 & 2000 & 13542 & 49896 & 128.8 & 9.5 \\
Administration & 18957.0 & 40663.9 & 0 & 2309 & 6912 & 18432 & 45694 & 119.1 & 8.0 \\
Other services & 6230.9 & 21977.9 & 0 & 0 & 0 & 4608 & 15000 & 353.9 & 14.0 \\
Sales personnel & 11149.6 & 44824.9 & 0 & 0 & 0 & 8640 & 22464 & 246.0 & 13.0 \\
\hline
\end{tabular}

Source: ENIA, 2001-2006, own computations. For the definition of labor categories, see table 1. 
Table 18 - OLS on robust subsample: Firms with 10-25 workers $^{a}$

\begin{tabular}{|c|c|c|c|c|c|c|}
\hline Real profit before taxes & \multicolumn{2}{|c|}{ Specification 1} & \multicolumn{2}{|c|}{ Specification 2} & \multicolumn{2}{|c|}{ Specification 3} \\
\hline Real capital & .0594 & $(.0044)$ & .0806 & $(.0026)$ & .0802 & $(.0026)$ \\
\hline Real capital (incl. profits) & .1278 & $(.0500)$ & .1490 & $(.0500)$ & .1486 & $(.0500)$ \\
\hline Real intermediate inputs & .0428 & $(.0022)$ & .0426 & $(.0023)$ & .0416 & $(.0023)$ \\
\hline Labor (all categories) & -.1103 & $(.0493)$ & & & & \\
\hline Labor category $1^{b}$ & & & -.7464 & $(.1847)$ & & \\
\hline Labor category 2 & & & -.0499 & $(.0558)$ & & \\
\hline Labor category 3 & & & -.1431 & $(.0805)$ & & \\
\hline Labor category 4 & & & -.1125 & $(.0539)$ & & \\
\hline Owners & & & & & -1.0856 & $(.2285)$ \\
\hline Managers & & & & & -.3702 & $(.2456)$ \\
\hline High-skilled (production) & & & & & -.0360 & $(.0563)$ \\
\hline Low-skilled (production) & & & & & -.1350 & $(.0513)$ \\
\hline Low-skilled (non-production) & & & & & -.0161 & $(.1622)$ \\
\hline Administration & & & & & -.2012 & $(.1242)$ \\
\hline Other services & & & & & .6027 & $(.2166)$ \\
\hline Sales personnel & & & & & -.1595 & $(.0767)$ \\
\hline Constant $^{c}$ & -8554.00 & $(2205.86)$ & -9133.43 & $(2252.83)$ & -8506.14 & $(2154.45)$ \\
\hline Size robust subsample & & 6,112 & & 6,114 & & 6,113 \\
\hline
\end{tabular}

Source: ENIA, 2001-2006, own computations.

${ }^{a}$ Bootstrap standard errors accounting for panel structure of the data in parentheses.

${ }^{b}$ Labor category $1=$ Owners, Managers

Labor category 2 = High-skilled (production), Administration

Labor category $3=$ Sales personnel

Labor category $4=$ Low-skilled (production and non-production), Other services

${ }^{c}$ Also includes time dummies. Omitting constant and time dummies changes results only marginally. 
Table 19 - OLS on robust subsample: Firms with 26-100 workers ${ }^{a}$

\begin{tabular}{|c|c|c|c|c|c|c|}
\hline Real profit before taxes & \multicolumn{2}{|c|}{ Specification 1} & \multicolumn{2}{|c|}{ Specification 2} & \multicolumn{2}{|c|}{ Specification 3} \\
\hline Real capital & .0651 & $(.0026)$ & .0652 & $(.0026)$ & .0650 & $(.0026)$ \\
\hline Real capital (incl. profits) & -.1368 & $(.0279)$ & -.1367 & $(.0279)$ & -.1369 & $(.0279)$ \\
\hline Real intermediate inputs & .0516 & $(.0024)$ & .0517 & $(.0024)$ & .0525 & $(.0023)$ \\
\hline Labor (all categories) & -.2171 & $(.0368)$ & & & & \\
\hline Labor category $1^{b}$ & & & -.4250 & $(.3378)$ & & \\
\hline Labor category 2 & & & -.2363 & $(.0552)$ & & \\
\hline Labor category 3 & & & -.3063 & $(.1261)$ & & \\
\hline Labor category 4 & & & -.1989 & $(.0393)$ & & \\
\hline Owners & & & & & -.9863 & $(.6024)$ \\
\hline Managers & & & & & -.0854 & $(.3928)$ \\
\hline High-skilled (production) & & & & & -.1978 & $(.0642)$ \\
\hline Low-skilled (production) & & & & & -.1600 & $(.0445)$ \\
\hline Low-skilled (non-production) & & & & & -.4082 & $(.1242)$ \\
\hline Administration & & & & & -.3201 & $(.1624)$ \\
\hline Other services & & & & & -.3725 & $(.2516)$ \\
\hline Sales personnel & & & & & -.2656 & $(.1275)$ \\
\hline Constant $^{c}$ & 2629.47 & $(4848.45)$ & 3497.51 & $(4936.93)$ & 3547.66 & $(5068.14)$ \\
\hline Size robust subsample & & 6,759 & & 6,759 & & 6,753 \\
\hline
\end{tabular}

Source: ENIA, 2001-2006, own computations.

${ }^{a}$ Bootstrap standard errors accounting for panel structure of the data in parentheses.

${ }^{b}$ Labor category $1=$ Owners, Managers

Labor category 2 = High-skilled (production), Administration

Labor category $3=$ Sales personnel

Labor category $4=$ Low-skilled (production and non-production), Other services

${ }^{c}$ Also includes time dummies. Omitting constant and time dummies changes results only marginally. 
Table 20 - OLS on robust subsample: Firms with 101-1000 workers ${ }^{a}$

\begin{tabular}{|c|c|c|c|c|c|c|}
\hline Real profit before taxes & \multicolumn{2}{|c|}{ Specification 1} & \multicolumn{2}{|c|}{ Specification 2} & \multicolumn{2}{|c|}{ Specification 3} \\
\hline Real capital & .1094 & $(.0045)$ & .1084 & $(.0046)$ & .1036 & $(.0049)$ \\
\hline Real capital (incl. profits) & -.3583 & $(.0276)$ & -.3593 & $(.0276)$ & -.3640 & $(.0276)$ \\
\hline Real intermediate inputs & .0882 & $(.0042)$ & .0882 & $(.0040)$ & .0986 & $(.0044)$ \\
\hline Labor (all categories) & .1303 & $(.0804)$ & & & & \\
\hline Labor category $1^{b}$ & & & -4.937 & $(2.4052)$ & & \\
\hline Labor category 2 & & & .3600 & $(.1615)$ & & \\
\hline Labor category 3 & & & -.5802 & $(.3364)$ & & \\
\hline Labor category 4 & & & .1793 & $(.1008)$ & & \\
\hline Owners & & & & & -14.9068 & $(7.3548)$ \\
\hline Managers & & & & & -1.7233 & $(2.4516)$ \\
\hline High-skilled (production) & & & & & .3551 & $(.1796)$ \\
\hline Low-skilled (production) & & & & & .1063 & $(.1117)$ \\
\hline Low-skilled (non-production) & & & & & .6729 & $(.3934)$ \\
\hline Administration & & & & & -1.3032 & $(.7065)$ \\
\hline Other services & & & & & .7319 & $(1.0783)$ \\
\hline Sales personnel & & & & & -.5335 & $(.3478)$ \\
\hline Constant $^{c}$ & $7.9 e+04$ & $(6.6 e+04)$ & $1.1 \mathrm{e}+05$ & $(6.0 e+04)$ & $1.2 \mathrm{e}+05$ & $(7.0 \mathrm{e}+04)$ \\
\hline Size robust subsample & & 3,645 & & 3,645 & & 3,646 \\
\hline
\end{tabular}

Source: ENIA, 2001-2006, own computations.

${ }^{a}$ Bootstrap standard errors accounting for panel structure of the data in parentheses.

${ }^{b}$ Labor category $1=$ Owners, Managers

Labor category $2=$ High-skilled (production), Administration

Labor category $3=$ Sales personnel

Labor category $4=$ Low-skilled (production and non-production), Other services

${ }^{c}$ Also includes time dummies. Omitting constant and time dummies changes results only marginally. 
Table 21 - OLS on robust subsample: Firms with 10-1000 workers $^{a}$

\begin{tabular}{|c|c|c|c|c|c|c|}
\hline Real profit before taxes & \multicolumn{2}{|c|}{ Specification 1} & \multicolumn{2}{|c|}{ Specification 2} & \multicolumn{2}{|c|}{ Specification 3} \\
\hline Real capital & .0782 & $(.0016)$ & .0731 & $(.0018)$ & .0483 & $(.0012)$ \\
\hline Real capital (incl. profits) & -.0889 & $(.0295)$ & -.0940 & $(.0295)$ & -.1187 & $(.0294)$ \\
\hline Real intermediate inputs & .0294 & $(.0008)$ & .0561 & $(.0012)$ & .0356 & $(.0008)$ \\
\hline Labor (all categories) & -.0956 & $(.0113)$ & & & & \\
\hline Labor category $1^{b}$ & & & -.9479 & $(.2223)$ & & \\
\hline Labor category 2 & & & -.1804 & $(.0254)$ & & \\
\hline Labor category 3 & & & -.1833 & $(.0523)$ & & \\
\hline Labor category 4 & & & -.1370 & $(.0144)$ & & \\
\hline Owners & & & & & -.8835 & $(.3612)$ \\
\hline Managers & & & & & -.1907 & $(.2679)$ \\
\hline High-skilled (production) & & & & & -.0805 & $(.0272)$ \\
\hline Low-skilled (production) & & & & & -.0375 & $(.0166)$ \\
\hline Low-skilled (non-production) & & & & & -.0517 & $(.0593)$ \\
\hline Administration & & & & & -.1870 & $(.0926)$ \\
\hline Other services & & & & & -.0607 & $(.1596)$ \\
\hline Sales personnel & & & & & -.1317 & $(.0455)$ \\
\hline Constant $^{c}$ & -5816.49 & $(2293.52)$ & -6663.40 & $(2346.48)$ & -1671.00 & $(2427.88)$ \\
\hline Size robust subsample & & 14,888 & & 14,882 & & 14,867 \\
\hline
\end{tabular}

Source: ENIA, 2001-2006, own computations.

${ }^{a}$ Bootstrap standard errors accounting for panel structure of the data in parentheses.

${ }^{b}$ Labor category $1=$ Owners, Managers

Labor category 2 = High-skilled (production), Administration

Labor category $3=$ Sales personnel

Labor category $4=$ Low-skilled (production and non-production), Other services

${ }^{c}$ Also includes time dummies. Omitting constant and time dummies changes results only marginally. 